\title{
Role of L-ascorbate in alleviating abiotic stresses in crop plants
}

\author{
Jelli Venkatesh and Se Won Park*
}

\begin{abstract}
L-ascorbic acid (vitamin C) is a major antioxidant in plants and plays a significant role in mitigation of excessive cellular reactive oxygen species activities caused by number of abiotic stresses. Plant ascorbate levels change differentially in response to varying environmental stress conditions, depending on the degree of stress and species sensitivity. Successful modulation of ascorbate biosynthesis through genetic manipulation of genes involved in biosynthesis, catabolism and recycling of ascorbate has been achieved. Recently, role of ascorbate in alleviating number of abiotic stresses has been highlighted in crop plants. In this article, we discuss the current understanding of ascorbate biosynthesis and its antioxidant role in order to increase our comprehension of how ascorbate helps plants to counteract or cope with various abiotic stresses.
\end{abstract}

Keywords: Abiotic stress; Antioxidant; L-ascorbate; Reactive oxygen species; Transgenics

\section{Review}

\section{Introduction}

Adverse environmental factors such as excessive cold, heat, drought and salinity stresses result in a considerable yield loss of crop plants all over the world. These abiotic stresses elicit complex cellular responses in the plant system, resulting in the production of excessive reactive oxygen species (ROS) such as hydrogen peroxide $\left(\mathrm{H}_{2} \mathrm{O}_{2}\right)$, hydroxyperoxyl $\left(\mathrm{HO}_{2} \cdot\right)$, superoxide $\left(\mathrm{O}_{2}^{-}\right)$and singlet oxygen $\left({ }^{1} \mathrm{O}_{2}\right)$ radicals. Excessive ROS generated in plant cells tends to interact with different macromolecules resulting in oxidation of proteins, membrane lipids and nucleic acids and causes cellular damage, ultimately affecting the growth and productivity of plants (Wang et al. 2003). To protect themselves from adverse conditions, plants have evolved a number of cellular defense mechanisms including antioxidants such as ascorbate, glutathione and tocopherols as well as ROS-detoxifying enzymes such as superoxide dismutases, peroxidases and catalases (Inzé and Van Montagu 1995; Noctor and Foyer 1998).

Among the plant antioxidants, L-ascorbate is a major antioxidant playing a vital role in the mitigation of excessive ROS activity through enzymatic as well as nonenzymatic detoxification (Mittler 2002). It also acts as a

\footnotetext{
* Correspondence: sewpark@konkuk.ac.kr

Department of Molecular Biotechnology, Konkuk University, 1, Hwayang-dong, Gwangjin-gu, Seoul, Korea Republic
}

cell signaling modulator in numerous cellular processes including cell division, cell expansion and cell wall growth (Liso et al. 1984; Conklin and Barth 2004; Wolucka et al. 2005; Zhang et al. 2007). It is a cofactor for the number of enzymes such as violaxanthin de-epoxidase (VDE, xanthophyll cycle), 1-aminocyclopropane-1-carboxylic acid (ACC) oxidase (ethylene biosynthesis) and 2-oxoaciddependent dioxygenases (ABA and GA biosynthesis) (Eskling et al. 1997; Davey et al. 2000; Smirnoff 2000). Plants with low ascorbate biosynthesis are rather sensitive to various environmental stress conditions affecting their growth and development (Müller-Moulé et al. 2004; Huang et al. 2005; Alhagdow et al. 2007; Gao and Zhang 2008). Recently, it has been reported that ascorbate plays a crucial role in protection against various environmental stresses such as, drought (Hemavathi et al. 2011; Fotopoulos et al. 2008), salinity (Kwon et al. 2003; Huang et al. 2005; Wang et al. 2005; Sun et al. 2010a; Zhang et al. 2011; Venkatesh et al. 2012), ozone (Zheng et al. 2000; Sanmartin et al. 2003; Feng et al. 2010), low/high temperatures (Kwon et al. 2003; Larkindale et al. 2005) and high light intensity (Müller-Moulé et al. 2004; Talla et al. 2011). These studies on mutant and/or transgenic plants (summarized in the Table 1) with altered endogenous ASA levels proved that ascorbate plays a significant role in plant growth and development as well as abiotic stress tolerance. In this article, an attempt has been made to

\section{穴}


Table 1 Role of ascorbate in plant growth and development and abiotic stress tolerance

\begin{tabular}{|c|c|c|c|c|c|c|c|}
\hline Enzyme/protein & $\begin{array}{l}\text { Target } \\
\text { plant }\end{array}$ & Gene & Gene source & $\begin{array}{l}\text { Type of genetic } \\
\text { manipulation }\end{array}$ & Ascorbate content & Phenotypic changes & Reference \\
\hline $\begin{array}{l}\text { GDP-mannose } \\
\text { pyrophosphorylase }\end{array}$ & Tobacco & GMPase & Tomato & Overexpression & 2.0-4.0-fold increase & Increased tolerance to temperature stress & Wang et al. 2011 \\
\hline \multirow[t]{2}{*}{$\begin{array}{l}\text { Phosphomannose } \\
\text { Isomerase }\end{array}$} & \multirow[t]{2}{*}{ Arabidopsis } & PMI1 & Arabidopsis & RNAi & $0.47-0.65$-fold decrease & $\begin{array}{l}\text { No phenotypic changes under normal growth } \\
\text { conditions in both mutants }\end{array}$ & Maruta et al. 2008 \\
\hline & & PMI2 & - & T-DNA knockout & No change & & \\
\hline \multirow[t]{4}{*}{ Phosphomannomutase } & Tobacco & NbPMM & Tobacco & VIGS & Up to 3.0-fold decrease & - & \multirow[t]{3}{*}{ Qian et al. 2007} \\
\hline & \multirow[t]{2}{*}{ Arabidopsis } & NbPMM & Tobacco & WMEE & $0.2-0.5$-fold increase & - & \\
\hline & & AtPMM & Arabidopsis & Overexpression & $0.25-0.33$-fold increase & Increased tolerance to MV stress & \\
\hline & Tobacco & PMM & Acerola & Overexpression & 2.0-fold increase & - & Badejo et al. 2009 \\
\hline \multirow{3}{*}{$\begin{array}{l}\text { VTC4/Myoinositol } \\
\text { monophosphatase (IMP) }\end{array}$} & \multirow[t]{3}{*}{ Arabidopsis } & \multirow[t]{3}{*}{ VTC4 } & \multirow[t]{3}{*}{-} & \multirow[t]{3}{*}{ T-DNA knockout } & \multirow[t]{3}{*}{$0.61-0.75$-fold decrease } & $22.4 \%-34 \%$ decreases in myoinositol content & \multirow[t]{3}{*}{ Torabinejad et al. 2009} \\
\hline & & & & & & Slow seed germination under control conditions & \\
\hline & & & & & & $\begin{array}{l}\text { Slightly hypersensitive to } \mathrm{ABA} \text { and } \mathrm{NaCl} \text { during } \\
\text { seed germination }\end{array}$ & \\
\hline $\begin{array}{l}\text { GDP-L-galactose } \\
\text { phosphorylase }\end{array}$ & Arabidopsis & $\begin{array}{l}\text { vtc5-1 and } \\
\text { vtc5-2 }\end{array}$ & Arabidopsis & T-DNA knockout & 0.2 -fold decrease & $\begin{array}{l}\text { Plant growth retardation and bleaching of } \\
\text { the cotyledons }\end{array}$ & Dowdle et al. 2007 \\
\hline \multirow[t]{3}{*}{$\begin{array}{l}\text { L-Galactose } \\
\text { dehydrogenase }\end{array}$} & $\begin{array}{l}\text { Tobacco } \\
\text { (BY-2 cells) }\end{array}$ & L-GallDDH & Tobacco & Overexpression & 1.5-2.0-fold increase & Higher mitotic index in cells & Tokunaga et al. 2005 \\
\hline & & & & & & Reduced browning and cells death of cultures & \\
\hline & & & & & & Increased tolerance to MV & \\
\hline \multirow[t]{2}{*}{$\begin{array}{l}\text { L-galactono-1,4-lactone } \\
\text { dehydrogenase }\end{array}$} & $\begin{array}{l}\text { Tobacco } \\
\text { (BY-2 cells) }\end{array}$ & GLDH & Tobacco & $\begin{array}{l}\text { Antisense } \\
\text { downregulation }\end{array}$ & 0.30 -fold decrease & $\begin{array}{l}\text { Adversely effected plant cell division, growth } \\
\text { and structure of plant cell }\end{array}$ & Tabata et al. 2001 \\
\hline & Tobacco & RrGallDH & Rosa roxburghii & Overexpression & 2.1-fold increase & Enhanced tolerance to salt stress & Liu et al. 2013a \\
\hline \multirow{3}{*}{$\begin{array}{l}\text { Monodehydroascorbate } \\
\text { reductase }\end{array}$} & Tobacco & AtMDAR1 & Arabidopsis & Overexpression & Up to 2.2-fold increase & Enhanced tolerance to ozone, salt and PEG stresses & Eltayeb et al. 2007 \\
\hline & Tobacco & $A m-M D A R$ & Avicennia marina & Overexpression & Up to 2.0-fold increase & Increased tolerance to salt stress & Kavitha et al. 2010 \\
\hline & Tobacco & MDAR-OX & Arabidopsis & Overexpression & Up to 1.1-fold increase & No change in Aluminium tolerance & Yin et al. 2010 \\
\hline \multirow{5}{*}{$\begin{array}{l}\text { Dehydroascorbate } \\
\text { reductase }\end{array}$} & Tobacco & DHAR-OX & Arabidopsis & Overexpression & Up to 1.3 -fold increase & Increased tolerance to Al stress & Yin et al. 2010 \\
\hline & Tobacco & DHAR & Arabidopsis & Overexpression & 1.9-2.1-fold increase & Enhanced tolerance to ozone, drought and salinity & Eltayeb et al. 2006 \\
\hline & \multirow[t]{2}{*}{ Tobacco } & \multirow[t]{2}{*}{ DHAR } & Wheat & Overexpression & 2.1-fold increase & Increased ozone tolerance and NPR & \multirow[t]{2}{*}{ Chen and Gallie 2005} \\
\hline & & & Tobacco & $\begin{array}{l}\text { Antisense } \\
\text { downregulation }\end{array}$ & 0. 29-fold decrease & Substantially reduced stomatal area and low NPR & \\
\hline & Tobacco & DHAR & Human & Overexpression & No significant change & Enhanced tolerance to low temperature and $\mathrm{NaCl}$ & Kwon et al. 2003 \\
\hline
\end{tabular}


Table 1 Role of ascorbate in plant growth and development and abiotic stress tolerance (Continued)

\begin{tabular}{|c|c|c|c|c|c|c|c|}
\hline \multirow[t]{21}{*}{ Ascorbate peroxidase } & Tobacco & $t A P x$ & Tobacco & Overexpression & No change & $\begin{array}{l}\text { Increased tolerance to MV and chilling stresses } \\
\text { under light conditions }\end{array}$ & Yabuta et al. 2002 \\
\hline & & & Tobacco/Spinach & $\begin{array}{l}\text { Antisense } \\
\text { downregulation }\end{array}$ & - & Plants failed to grow & \\
\hline & Arabidopsis & HVAPX1 & Barley & Overexpression & - & Increased tolerance to salt stress & Xu et al. 2008 \\
\hline & Arabidopsis & $\begin{array}{l}\text { OsAPXa and } \\
\text { OsAPXb }\end{array}$ & Rice & Overexpression & - & Increased tolerance to salt stress & Lu et al. 2007 \\
\hline & Tobacco & CAPOA1 & Pepper & Overexpression & - & Increased plant growth & Sarowar et al. 2005 \\
\hline & & & & & & Increased tolerance to MV stress & \\
\hline & $\begin{array}{l}\text { Tobacco } \\
\text { BY-2 cells }\end{array}$ & CAPX & Arabidopsis & $\begin{array}{l}\text { Antisense } \\
\text { downregulation }\end{array}$ & No change & Increased tolerance against heat and salt stresses & Ishikawa et al. 2005 \\
\hline & Tobacco & StAPX & Tomato & Overexpression & - & Improved seed germination & Sun et al. 2010a \\
\hline & & & & & & Increased tolerance to salt and osmotic stresses & \\
\hline & Rice & $A p \times 1 / A p \times 2$ & Rice & RNAi (Apx1+ Apx2) & Up to 1.5 -fold decrease & No change in plant growth and development & Rosa et al. 2010 \\
\hline & & & & & & Increased tolerance to aluminium & \\
\hline & & & & RNAi (Apx1 or Apx2) & - & Produced semi-dwarf phenotype & \\
\hline & Rice & OsAPx-R & Rice & RNAi & - & Delayed plant development & Lazzarotto et al. 2011 \\
\hline & Rice & OsAPXa & Rice & Overexpression & - & Increased spikelet fertility under cold stress & Sato et al. 2011 \\
\hline & Rice & Osapx2 & Rice & Overexpression & - & Enhanced stress tolerance & Zhang et al. 2013 \\
\hline & & & & & & Sensitive to abiotic stresses & \\
\hline & & & - & T-DNA knockout & - & $\begin{array}{l}\text { Semi-dwarf seedlings, yellow-green leaves, leaf } \\
\text { lesion-mimic and seed sterility }\end{array}$ & \\
\hline & Alfalfa & Osapx2 & Rice & Overexpression & - & Increased salt resistance & Guan et al. 2012 \\
\hline & Tomato & CAPX & Pea & Overexpression & - & Enhanced tolerance to UV-B and heat stresses & Wang et al. 2006 \\
\hline & Tomato & CAPX & Pea & Overexpression & - & Enhanced tolerance to chilling and salt stresses & Wang et al. 2005 \\
\hline & Tomato & LetAPX & Tomato & $\begin{array}{l}\text { Antisense } \\
\text { downregulation }\end{array}$ & No significant change & $\begin{array}{l}\text { Transgenic plants photosynthetically less efficient } \\
\text { and sensitive to chilling stress }\end{array}$ & Duan et al. 2012b \\
\hline \multirow[t]{5}{*}{ Ascorbate oxidase } & Tobacco & $A A O$ & Cucumber & Overexpression & No change & Plants become susceptible to ozone & Sanmartin et al. 2003 \\
\hline & Tobacco & $A A O$ & Cucumber & Overexpression & No change & $\begin{array}{l}\text { Increased drought tolerance due to reduced } \\
\text { stomatal conductance }\end{array}$ & Fotopoulos et al. 2008 \\
\hline & Tobacco & $A A O$ & Pumpkin & Overexpression & $\begin{array}{l}\text { 2.0-fold increase in } \\
\text { apoplastic ASA }\end{array}$ & $\begin{array}{l}\text { Number of smaller flowers significantly increased } \\
6 \% \text { to } 14 \% \text { reduction of in seed weight }\end{array}$ & Pignocchi et al. 2003 \\
\hline & & & Tobacco & $\begin{array}{l}\text { Antisense } \\
\text { downregulation }\end{array}$ & $\begin{array}{l}\text { 2.0-fold increase in } \\
\text { apoplastic ASA }\end{array}$ & No significant changes & \\
\hline & Tobacco & $A A O$ & Tobacco & Overexpression & - & $\begin{array}{l}\text { Severe inhibition of germination and seed yield } \\
\text { under high salinity }\end{array}$ & Yamamoto et al. 2005 \\
\hline
\end{tabular}


Table 1 Role of ascorbate in plant growth and development and abiotic stress tolerance (Continued)

\begin{tabular}{|c|c|c|c|c|c|c|c|}
\hline & Tobacco & $A A O$ & Tobacco & $\begin{array}{l}\text { Antisense } \\
\text { downregulation }\end{array}$ & - & Increased tolerance to salt stress & Yamamoto et al. 2005 \\
\hline & & & & & - & Increased seed yield under salt stress & \\
\hline & Arabidopsis & $A A O$ & - & T-DNA knockout & & Increased tolerance to salt stress & \\
\hline & & & & & & Increased seed yield under salt stress & \\
\hline Myoinositol oxygenase & Rice & OsMIOX & Rice & Overexpression & No change & Increased drought tolerance & Duan et al. 2012a \\
\hline $\begin{array}{l}\text { ASA mannose pathway } \\
\text { regulator } 1\end{array}$ & Arabidopsis & $A M R 1$ & - & T-DNA knockout & 2.0-3.0-fold increase & Increased ozone tolerance & Zhang et al. 2009 \\
\hline
\end{tabular}

APX-R, APX-related; CAPOA1, Capsicum annuum ascorbate peroxidase-like 1 gene; MV, methyl viologen; NPR, net photosynthetic rate; PEG, polyethylene glycol; RNAi, RNA interference; VIGS, Virus-induced gene silencing; WMEE, Viral-vector-mediated ectopic- expression. 
illustrate the role of ascorbate in various abiotic stresses in crop plants by exploring transgenic technology.

\section{Overview: ascorbic acid biosynthesis, transportation,} recycling and degradation processes in plants

In plants, the accumulation or steady level of ascorbate is maintained in homeostasis through the rate of synthesis, recycling and degradation, as well as intra- and inter-cellular transport (Horemans et al. 2000a; Pallanca and Smirnoff 2000; Green and Fry 2005).

\section{Biosynthesis}

Characterization of low ascorbate producing mutants $(v t c)$ of Arabidopsis has helped us to better understand the essential role of enzymes involved in the biosynthesis of L-ascorbate (Conklin et al. 1996; Conklin et al. 2000; Huang et al. 2005; Conklin et al. 2006; Müller-Moulé 2008). Now it is well known that in higher plants, ascorbate biosynthesis occurs through well-characterized D-mannose/L-galactose pathway (Smirnoff-Wheeler pathway), where $\mathrm{D}$-mannose is converted to L-galactose via GDP-sugar intermediates (Wheeler et al. 1998) (Figure 1). L-galactose is further oxidized to L-galactono-1,4-lactone, which is converted into ascorbate, by L-galactono-1,4-lactone dehydrogenase (L-GalLDH), located on the inner mitochondrial membrane (Siendones et al. 1999; Smirnoff 2001). All of the genes that are involved in this pathway have been well-characterized; these include genes encoding

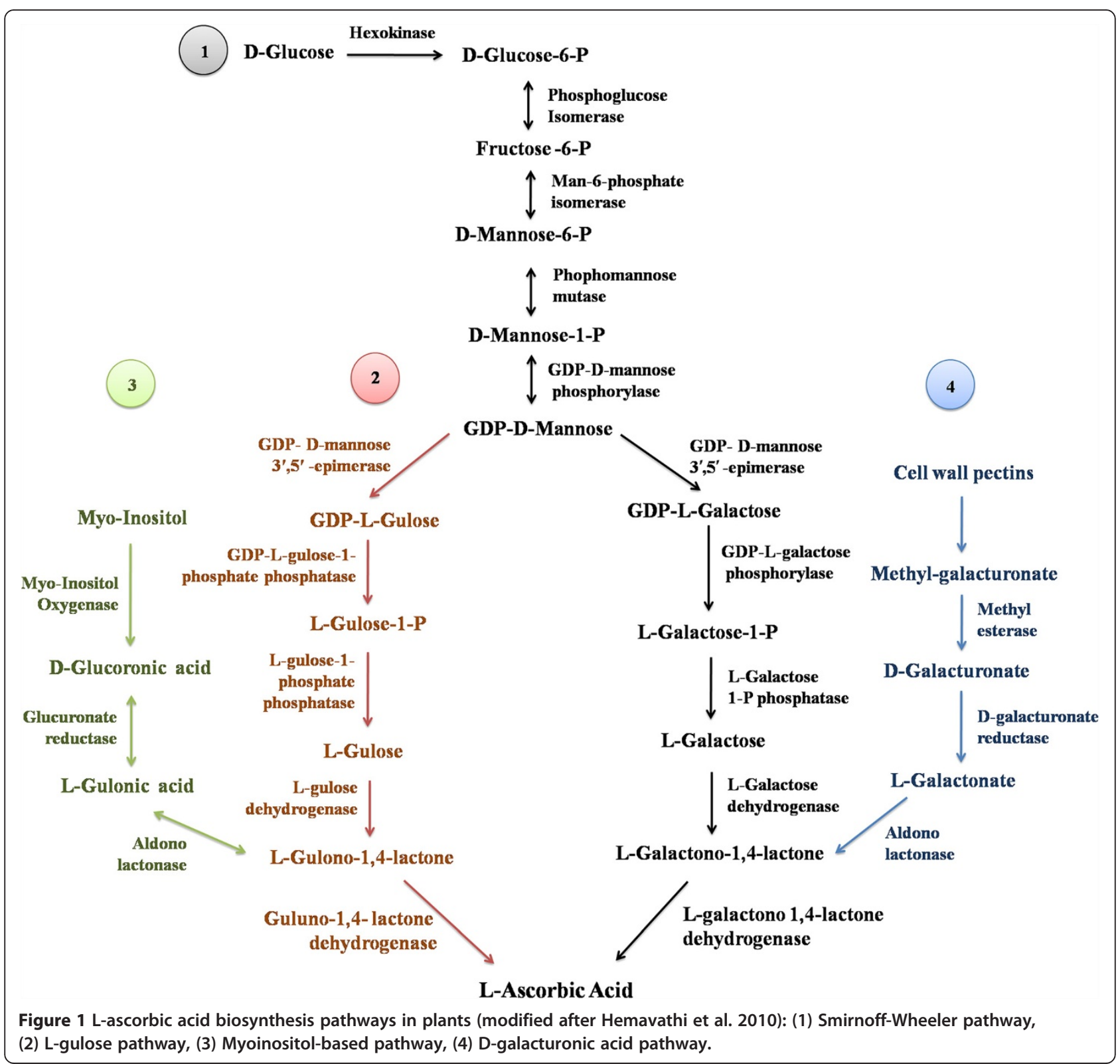


GDP-D-mannose pyrophosphorylase (Conklin et al. 1999), GDP-D-mannose-3,5'-epimerase (Wolucka and Van Montagu 2003; Watanabe et al. 2006), GDP-L-galactose phosphorylase (L-galactose guanylyltransferase) (Dowdle et al. 2007; Linster and Clarke 2008), L-galactose-1-phosphate phosphatase (Laing et al. 2004a), L-galactose dehydrogenase (Gatzek et al. 2002; Laing et al. 2004b) and L-GalLDH (Imai et al. 1998; Siendones et al. 1999; do Nascimento et al. 2005; Tokunaga et al. 2005; Alhagdow et al. 2007).

In addition to the Smirnoff-Wheeler pathway, three other potential pathways of ascorbate biosynthesis have been identified in plants. It was demonstrated that in addition to production of GDP-L-galactose, GDP-Dmannose-3',5'-epimerase can also produce GDP-L-gulose (Davey et al. 1999; Wolucka and Van Montagu 2003). Moreover, exogenous L-gulose and L-gulono-1,4-lactone were shown to serve as direct precursors of ascorbate in Arabidopsis cell cultures (Davey et al. 1999). These observations led to a proposal for an alternative L-gulose pathway in which L-gulose and L-gulono-1,4-lactone are important intermediates (Wolucka and Van Montagu 2003). However, the intermediate steps in this pathway have not yet been characterized in plants. D-galacturonic acid pathway involves the conversion of $\mathrm{D}$-galacturonic acid, a product of the degradation of cell wall pectins to Lascorbate via L-galactono-1,4-lactone (Agius et al. 2003; Cruz-Rus et al. 2011; Badejo et al. 2012) (Figure 1). Following the cloning of Arabidopsis myoinositol oxygenase (MIOX) gene by Lorence et al. (2004), a myoinositolbased pathway (animal-like pathway) was proposed (Figure 1). MIOX converts myoinositol to D-glucuronate and plants can catalyze the conversion of D-glucuronate into L-gulonic acid. However, recently, Endres and Tenhaken (2009), proved that the MIOX is involved mainly in the modulation of the metabolite level of myoinositol and plays a negligible role in the plant ascorbate biosynthesis.

\section{Ascorbate transport}

Once the ascorbate is synthesized on the inner mitochondrial membrane, it is transported to different cellular compartments including the apoplast. Both the ascorbate and DHA transport is mainly mediated by facilitated diffusion or active transport systems (Ishikawa et al. 2006). In contrast to ascorbate, DHA tends to be more efficiently transported across plant membranes with a higher affinity and capacity (Horemans et al. 1998; Szarka et al. 2004). It was proposed that specific plasma membrane transporters transport ASA or DHA in plants (Horemans et al. 2000b). However, either the protein or the gene associated with this transport and the nature of the mechanisms driving these carrier proteins are still inconclusive. Several other putative ascorbate transporters are associated with the plant plasma membrane (reviewed in Horemans et al. 2000a); however, the specific mechanisms by which they transport ASA or DHA have not been well elucidated.

Ascorbate biosynthesis occurs in almost all plant cells and tissues. However, its level is generally high in photosynthetic tissues, meristematic tissues, flowers, young fruits, root tips, and apices of stolons or tubers (Gest et al. 2013). In certain fruits, such as Ribes nigrum (by galactose pathway, Hancock et al. 2007) and strawberry (by D-galacturonic acid pathway, Agius et al. 2003), increased accumulation of ascorbate occurs by a combination of long-distance transport and in situ biosynthesis. High ascorbate demand in developing sink tissues is probably because it is critical for cell cycle and cell division/growth, which cannot be met entirely by sink tissue alone (Smirnoff 2000; Franceschi and Tarlyn 2002). Ascorbate accumulation in sink tissue is controlled to some extent by ascorbate biosynthesis in source tissues (Franceschi and Tarlyn 2002; Tedone et al. 2004). Franceschi and Tarlyn (2002), demonstrated that the long-distance transport of ASA in plants occurs via phloem, where L-ascorbate was found to be loaded into the phloem of source leaves and transported to sink tissues. In addition, ascorbate biosynthesis, which occurs in phloem tissue via the D-Man/L-Gal pathway could also contribute to ASA accumulation in plant storage organs (Hancock et al. 2003).

In mammals, sodium-dependent ascorbate transporters (SVCT1 and SVCT2), which belong to the nucleobaseascorbate transporter (NAT) family, have been identified and well characterized as an active ascorbate transport system (Daruwala et al. 1999; Tsukaguchi et al. 1999; Ishikawa et al. 2006). Although numerous NATs have been identified in plants ( $\mathrm{Li}$ and Schultes 2002; Maurino et al. 2006), their role in ASA transportation has not been established. Further studies are required to determine the definitive role in plant ascorbate transportation.

\section{Ascorbate recycling}

ASA pool in cells is maintained through synthesis, recycling and transportation, and plays an important role in adaptation of plant to various stresses (Stevens et al. 2008). Ascorbate takes part in several enzymatic and non-enzymatic mechanisms for elimination of deleterious ROS (Asada and Takahashi 1987), and as a result, MDHA and DHA accumulates in the cells. The two enzymes involved in the oxidation of ascorbate are ascorbate oxidase (AAO) and ascorbate peroxidase (APX). $\mathrm{AAO}$ is an apoplastic enzyme that catalyzes the oxidation of ASA to MDHA using oxygen and is associated with cell wall metabolism and cell expansion (Smirnoff 1996). Ascorbate peroxidase (APX) is a class I peroxidase catalyzes the conversion of $\mathrm{H}_{2} \mathrm{O}_{2}$ into $\mathrm{H}_{2} \mathrm{O}$, using ascorbate as a specific electron donor, thus resulting in the 
accumulation of MDHA as a by-product (Teixeira et al. 2004).

The ASA pool size is dependent, on both the rate of synthesis and the rate of reduction of MDHA and DHA back to ascorbate. MDHA and DHA produced as a result of activities of APX and AAO, respectively, should be efficiently recycled to maintain the reduced pool of ASA. MDHA is reduced back to ASA by MDAR using $\mathrm{NADH} / \mathrm{NADPH}$ as electron donors. In addition, plant PM cyt b 561 (plasma membrane b-type cytochrome $c$ ) is also associated with the recycling of ASA from MDHA on the cytoplasmic side of the plasma membrane (Trost et al. 2000; Asard et al. 2001; Pignocchi and Foyer 2003). DHA is reduced to ASA by dehydroascorbate reductase (DHAR) using reduced glutathione (GSH) as an electron donor or by the electron-transport chain (ETC.) electron carriers (Szarka et al. 2007). Thus, DHAR and MDAR are crucial components in the maintenance of the reduced pool of ASA and are of prime importance in oxidative stress tolerance (Eltayeb et al. 2006).

\section{Ascorbate degradation}

Although the pathway of ascorbate synthesis is distributed between the cytosol and the mitochondrion (Foyer 2004; Smirnoff et al. 2004), the ascorbate degradation pathway appears to reside in the apoplast (Green and Fry 2005). In most plants, ascorbate degradation can occur via dehydroascorbate, yielding oxalate (OxA) and L-threonate (ThrO). However, in some plants (Vitaceae eg. grape), ascorbate can also be degraded via L-idonate to L-threarate (L-tartrate) (Green and Fry 2005). A degradation pathway for ASA/DHA catabolism in plants has been reported recently (Simpson and Ortwerth 2000; Parsons and Fry 2012). Ascorbate degradation pathway involves enzymic and/or non-enzymic oxidation to dehydroascorbic acid (DHA), which may irreversibly hydrolyze to 2,3-diketogulonate (DKG). However, many of the enzymes involved in the degradation pathway of ASA are not well characterized in plants. Both DHA and DKG prone to further oxidation under the same physiological conditions as that of apoplast (Parsons and Fry 2012). DHA can be oxidized by $\mathrm{H}_{2} \mathrm{O}_{2}$ non-enzymatically to a monoanion (cyclic-oxalyl-threonate; $\mathrm{COxT}$ ) and a dianion (oxalyl-threonate $[\mathrm{OxT}]$ isomers, 3-OxT and 4-OxT) independently through formation of a reactive intermediate cyclic-2,3-O-oxalyl-L-threonolactone (Parsons et al. 2011). In the absence of $\mathrm{H}_{2} \mathrm{O}_{2}$, DKG is relatively stable, however slowly generates a range of products, such as 2carboxy-l-xylonolactone, 2-carboxy-l-lyxonolactone and 2-carboxy-l-threo-pentonate (Parsons et al. 2011). In the presence of apoplastic plant esterases or prolonged nonenzymatic incubations, substantial hydrolysis of cOxT to OxT and then OxT to OxA and ThrO would take place (Parsons et al. 2011).
Genetic modulation of plant ascorbate pathway has become feasible with advancements made in plant genomics and genetic engineering. Several possible strategies have been followed to increase ascorbate production in plants via genetic engineering of enzymes involved in the biosynthesis and recycling of ascorbate. Several transgenes, which are of plant and animal origins, have been successfully used for increasing biosynthesis of ascorbic acid. Mouse L-gulono-c-lactone oxidase (GLOase) gene in tobacco, lettuce and potato (Jain and Nessler 2000; Hemavathi et al. 2010), human dehydroascorbate (DHAR) gene in tobacco (Kwon et al. 2003), wheat DHAR gene in tobacco and maize (Chen et al. 2003; Naqvi et al. 2009), Arabidopsis MDAR gene (AtMDAR1) in tobacco, strawberry D-galacturonic acid reductase (GalUR) gene in Arabidopsis and potato (Agius et al. 2003; Hemavathi et al. 2009) and rice L-GalLDH gene in rice (Liu et al. 2011) have been successfully cloned and expressed (summarized in the Table 2).

\section{Role of ascorbate in photosynthesis as a photoprotectant}

A high concentration of ascorbate in chloroplasts would imply its central role in photosynthesis (Smirnoff 1996). Ascorbate plays a crucial roles in scavenging the deleterious ROS that are generated as by-products of photosynthesis and as a key component in excess photonic energy dissipation mechanisms, such as the water-water cycle (WWC) (Neubauer and Yamamoto 1992; Asada 1999) and the xanthophyll cycle (Müller-Moulé et al. 2002; Yabuta et al. 2007). WWC, which is also known as Mehler peroxidase reaction, is one of the most important detoxification systems functioning in intact chloroplasts (Asada 1994, 1999, 2006). It involves the photoreduction of $\mathrm{O}_{2}$ by PSI to a superoxide radical, followed by the dismutation of superoxide radical by superoxide dismutase (SOD) to hydrogen peroxide and oxygen (Müller-Moulé et al. 2002). The hydrogen peroxide is reduced to water by ascorbate, catalyzed by ascorbate peroxidase (APX), and the resulting by-product monodehydroascorbate (MDA) is directly reduced to ascorbate either by reduced ferredoxin of PSI (Miyake and Asada 1992; Miyake and Asada 1994; Asada 1999) or by NAD(P)H-dependent chloroplastic MDHA reductase using NADH or NADPH as electron donor (Sano et al. 2005). MDHA can spontaneously disproportionate to ascorbate and dehydroascorbate (DHA) (Asada 1999). DHA is unstable at the physiological pH and irreversibly degrade to 2,3 diketo-1-gulonic acid if not recycled back to ascorbate. To preserve the ascorbate pool, DHA should be rapidly reduced back to ascorbate. DHA is recycled back to ascorbate via the ascorbateglutathione cycle by reduced glutathione (GSH), catalyzed by DHAR (Shimaoka et al. 2003). Finally, glutathione reductase (GR) converts glutathione disulfide (GSSG) back 
Table 2 Transgenic approaches for overproduction of L-ascorbate in plants

\begin{tabular}{|c|c|c|c|c|c|c|c|}
\hline Enzyme & Target plant & Gene & Gene source & $\begin{array}{l}\text { Type of genetic } \\
\text { manipulation }\end{array}$ & Ascorbate content & Phenotypic change & Reference \\
\hline \multirow{3}{*}{$\begin{array}{l}\text { GDP-I-galactose } \\
\text { phosphorylases }\end{array}$} & Tomato & GGP/VTC2 & Actinidia chinensis & Overexpression & 3.0-6.0-fold increase in fruits & - & Bulley et al. 2012 \\
\hline & Strawberry & & & Overexpression & 2.0-fold increase in fruits & - & \\
\hline & Potato & & $\begin{array}{l}\text { Potato/ } \\
\text { Arabidopsis }\end{array}$ & Overexpression & Up to 3.0-fold increase in tuber & - & \\
\hline \multirow[t]{2}{*}{$\begin{array}{l}\text { GDP-mannose } \\
\text { pyrophosphorylase }\end{array}$} & Potato & GMPase & Potato & $\begin{array}{l}\text { Antisense } \\
\text { downregulation }\end{array}$ & $0.88-1.44$-fold reduction in leaves & Dark spots on leaf veins and stems & Keller et al. 1999 \\
\hline & & & & & 0.56 -fold reduction in tubers & Early senesce & \\
\hline \multirow[t]{4}{*}{$\begin{array}{l}\text { GDP-Mannose } \\
\text { 3',5'-epimerase }\end{array}$} & Tomato & SIGMEI & Tomato & Overexpression & Up to 1.42 -fold increase in leaves & $\begin{array}{l}\text { Improved tolerance to various abiotic } \\
\text { stresses such as cold, salt and MV }\end{array}$ & Zhang et al. 2011 \\
\hline & & & & & Up to 1.60 -fold increase in fruits & & \\
\hline & & SIGME2 & & Overexpression & Up to 1.37 -fold increase in leaves & & \\
\hline & & & & & Up to 1.24 -fold increase in fruits & & \\
\hline $\begin{array}{l}\text { L-galactose } \\
\text { guanyltransferase }\end{array}$ & Tobacco & GalT & Kiwifruit & $\begin{array}{l}\text { Transient expression } \\
\text { (leaves) }\end{array}$ & Up to 3.0-fold increase & - & Laing et al. 2007 \\
\hline \multirow{2}{*}{$\begin{array}{l}\text { L-Galactose } \\
\text { dehydrogenase }\end{array}$} & Tobacco & L-GalDH & Arabidopsis & Overexpression & No change & - & Gatzek et al. 2002 \\
\hline & Arabidopsis & & Arabidopsis & $\begin{array}{l}\text { Antisense } \\
\text { downregulation }\end{array}$ & 0.7-fold decrease & - & \\
\hline \multirow{5}{*}{$\begin{array}{l}\text { L-galactono-1,4-lactone } \\
\text { dehydrogenase }\end{array}$} & Rice & L-GalLDH & Rice & RNAi & $0.6-0.87$-fold decrease & Slow plant growth rate and poor seed set & Liu et al. 2011 \\
\hline & & & Rice & Overexpression & Up to 1.48 -fold increase & Increased NPR and higher seed set & \\
\hline & Tomato & SIGalLDH & Tomato & RNAi & No change & Slow plant growth rate & Alhagdow et al. 2007 \\
\hline & & & & & & Strong reduction in leaf and fruit size & \\
\hline & Rice & L-GallDH & Rice & RNAi & 0.3 - 0.5 -fold decrease & $\begin{array}{l}\text { Slow growth rate, reduced tiller number, } \\
\text { decreased NPR and premature senescence }\end{array}$ & Liu et al. 2013b \\
\hline \multirow{5}{*}{$\begin{array}{l}\text { L-gulono-c-lactone } \\
\text { oxidase }\end{array}$} & Arabidopsis & GLOase & Rat & Overexpression & Up to $2.0-3.0$-fold increase & - & Radzio et al. 2003 \\
\hline & Lettuce & GLOase & Rat & Overexpression & 4.0-7.0-fold increase & - & Jain and Nessler 2000 \\
\hline & Tobacco & & & Overexpression & Up to 7.0 -fold increase & - & \\
\hline & Tomato & GLOase & Rat & Overexpression & 1.5 -fold increase in fruits & $\begin{array}{l}\text { Enhanced tolerance to } \mathrm{MV}, \mathrm{NaCl} \\
\text { and mannitol }\end{array}$ & Lim et al. 2012 \\
\hline & Potato & GLOase & Rat & Overexpression & Up to 1.41 -fold increase & $\begin{array}{l}\text { Enhanced tolerance to } \mathrm{MV}, \mathrm{NaCl} \\
\text { and mannitol }\end{array}$ & Hemavathi et al. 2010 \\
\hline \multirow{4}{*}{$\begin{array}{l}\text { D-galacturonic acid } \\
\text { reductase }\end{array}$} & Arabidopsis & GalUR & Strawberry & Overexpression & 2.0-3.0-fold increase & - & Agius et al. 2003 \\
\hline & Potato & GalUR & Strawberry & Overexpression & 1.6-2.0-fold increase & $\begin{array}{l}\text { Enhanced tolerance to } \mathrm{MV}, \mathrm{NaCl} \text {, } \\
\text { and mannitol }\end{array}$ & Hemavathi et al. 2009 \\
\hline & $\begin{array}{l}\text { Tomato } \\
\text { (Hairy Roots) }\end{array}$ & GalUR & Strawberry & Overexpression & 2.5-fold increase & High growth rate & Wevar Oller et al. 2009 \\
\hline & Tomato & LeMDAR & Tomato & Overexpression & Up to 1.18-fold increase & & Li et al. 2010 \\
\hline
\end{tabular}


Table 2 Transgenic approaches for overproduction of L-ascorbate in plants (Continued)

\begin{tabular}{|c|c|c|c|c|c|c|c|}
\hline \multirow[t]{5}{*}{$\begin{array}{l}\text { Monodehydroascorbate } \\
\text { reductase }\end{array}$} & & & & & & $\begin{array}{l}\text { Enhanced tolerance to temperature } \\
\text { (low/high) and MV stresses }\end{array}$ & \\
\hline & & & & & & High NPR & \\
\hline & & & & $\begin{array}{l}\text { Antisense } \\
\text { downregulation }\end{array}$ & Up to 1.3-fold decrease & Susceptible to various abiotic stresses & \\
\hline & Tomato & MDAR & Tomato & Overexpression & 0.7-fold reduced in fruits & - & Haroldsen et al. 2011 \\
\hline & & & & & No change in leaves & & \\
\hline \multirow{16}{*}{$\begin{array}{l}\text { Dehydroascorbate } \\
\text { reductase }\end{array}$} & Tomato & DHAR & Tomato & Overexpression & 1.6-fold increase in fruits & - & Haroldsen et al. 2011 \\
\hline & & & & & No change in leaves & & \\
\hline & Maize (Kernels) & DHAR & Wheat & Overexpression & 6.0-fold increase & - & Naqvi et al. 2009 \\
\hline & Maize & DHAR & Wheat & Overexpression & $\begin{array}{l}\text { Up to 1.8-fold (leaves) and } \\
1.9 \text {-fold (kernels) increase }\end{array}$ & - & Chen et al. 2003 \\
\hline & Tobacco & DHAR & Wheat & Overexpression & 2.2-3.9-fold increase & - & Chen et al. 2003 \\
\hline & Tobacco & DHAR & Rice & Overexpression & Up to 1.6 -fold increase & Enhanced tolerance to salt and cold stresses & Le Martret et al. 2011 \\
\hline & Tobacco & DHAR & Human & $\begin{array}{l}\text { Overexpression } \\
\text { (chloroplasts) }\end{array}$ & 1.1-fold increase & $\begin{array}{l}\text { Increased SOD and APX activities in } \\
\text { conjunction via triple gene construct }\end{array}$ & Lee et al. 2007 \\
\hline & & & & & & $\begin{array}{l}\text { Increased tolerance to } \mathrm{MV} \text { and } \mathrm{NaCl} \\
\text { induced stress }\end{array}$ & \\
\hline & Potato & DHAR & Sesame & Overexpression & $\begin{array}{l}1.1-1.3 \text {-fold increase in tuber } \\
\text { with patatin promoter }\end{array}$ & - & Goo et al. 2008 \\
\hline & & & & Overexpression & $\begin{array}{l}1.5-\text { and } 1.6-\text { fold increase in } \\
\text { leaves and tuber respectively, } \\
\text { with CaMV35S promoter }\end{array}$ & $\begin{array}{l}\text { 1.5- and } 1.6 \text {-fold increase in leaves and } \\
\text { tuber respectively, with CaMV35S promoter }\end{array}$ & \\
\hline & Potato & StDHAR1 & Potato & $\begin{array}{l}\text { Overexpression } \\
\text { (Cytosol) }\end{array}$ & Up to 0.69 -fold increase in leaves & - & Qin et al. 2011 \\
\hline & & & & & Up to 0.29 -fold increase in tubers & & \\
\hline & & & & & Up to 0.50 -fold increase in leaves & - & \\
\hline & & StDHAR2 & & $\begin{array}{l}\text { Overexpression } \\
\text { (Chloroplast) }\end{array}$ & No significant change in tubers & & \\
\hline & Arabidopsis & $D H A R 1$ & Rice & Overexpression & $>$ 1.4-fold increase & Enhanced tolerance to salt stress & Ushimaru et al. 2006 \\
\hline & Arabidopsis & DHAR & Arabidopsis & Overexpression & 2.0-4.25-fold increase & $\begin{array}{l}\text { Enhanced tolerance to high-light and } \\
\text { high-temperature stress }\end{array}$ & Wang et al. 2010 \\
\hline Myoinositol oxygenase & Arabidopsis & $\operatorname{miox} 4$ & Arabidopsis & Overexpression & 2.0-3.0-fold increase & - & Lorence et al. 2004 \\
\hline
\end{tabular}

MV, methyl viologen; NPR, net photosynthetic rate; RNAi, RNA interference. 
into GSH using $\mathrm{NAD}(\mathrm{P}) \mathrm{H}$ as a reducing agent (Figure 2). Recently, Huang et al. (2008), reported that thioredoxin $h 2(\operatorname{Trx} h 2)$ having both DHA reductase (in the presence of glutathione) and MDA reductase (in the presence of $\mathrm{NADH}$ ) activity may also involve in the regeneration of ascorbate from DHA and MDHA, respectively.

Increased biosynthesis of ascorbate in high light exposed plants and enhanced photoinhibition and oxidative damage in ascorbate-deficient plants would imply its role in excess light energy dissipation (Smirnoff 2000; Müller-Moulé et al. 2004; Yabuta et al. 2007). It was previously reported that high light stress results in the induction of the cytosolic APX and protects the cytosol and other cellular compartments from high light induced oxidative stress (Mittler 2002; Mullineaux and Karpinski 2002). Several isoforms of APX have been found in many plant species including both monocots and dicots, and are localized to various subcellular compartments. In Arabidopsis, nine APX genes were described (Panchuk et al. 2002; Mittler et al. 2004; Narendra et al. 2006; Koussevitzky et al. 2008): two cytosolic, two microsomal, three chloroplastic, one mitochondrial, and one dual-targeted to mitochondria and chloroplasts (Chew et al. 2003). In tomato, $A P X$ gene family comprises of seven genes encoding three cytosolic, two peroxisomal, and two chloroplastic APXs (Najami et al. 2008). Whereas, in rice, the APX gene family consists of eight genes encoding two cytosolic, two peroxisomal, and three chloroplastic isoforms and one is

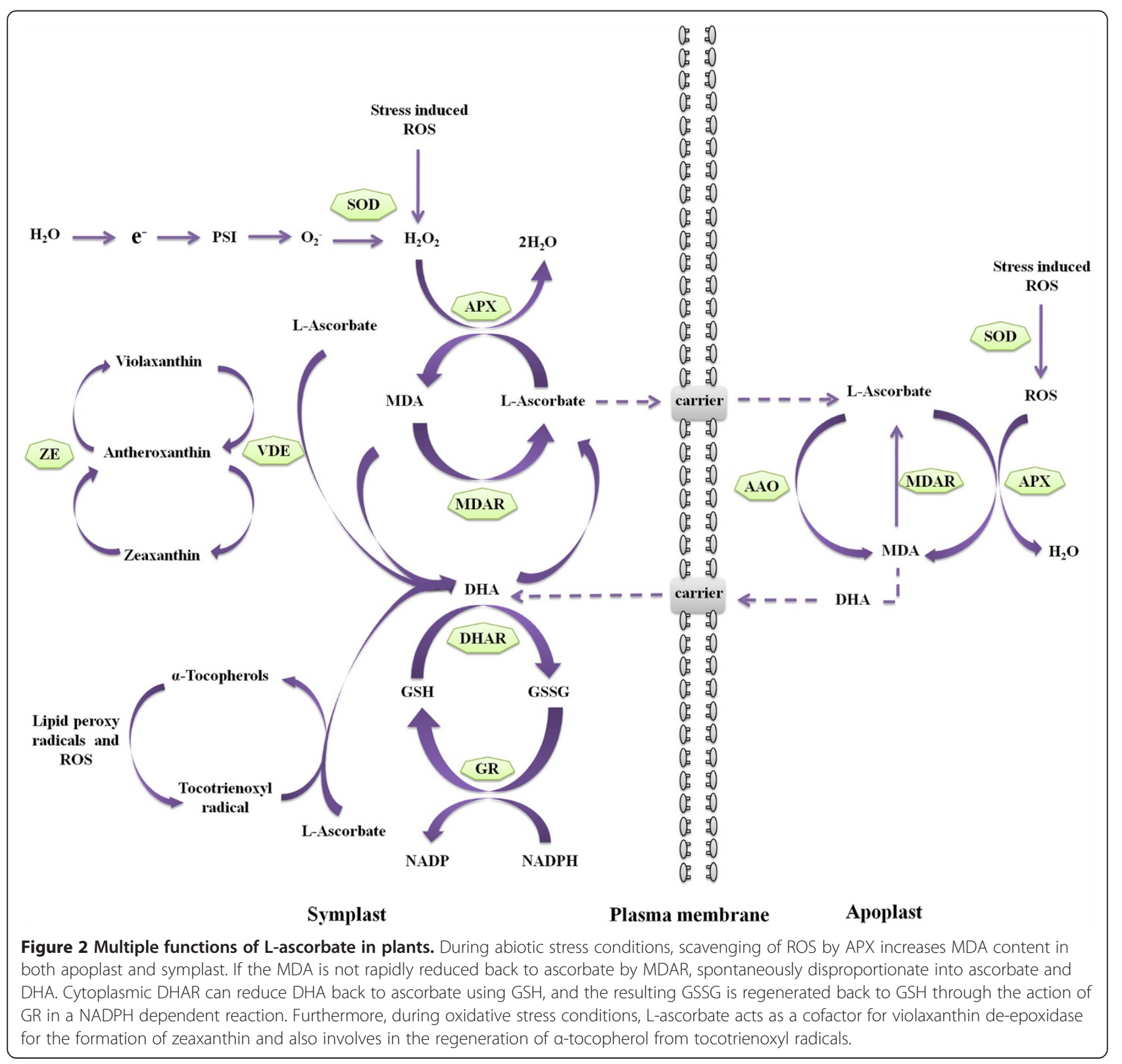


targeted to the mitochondria (Teixeira et al. 2004, 2006; Hong et al. 2007). Recently, Lazzarotto et al. (2011), characterized a new class of rice putative heme peroxidases, APX-R (APX-related), a dually localized protein, targeted to both chloroplasts and mitochondria, which is functionally associated with APX. APX genes have been partially characterized in some plant species such as spinach (Ishikawa et al. 1995, 1996, 1998), cowpea (D’Arcy-Lameta et al. 2006) and eggplant (Lin et al. 2007). The large functional diversity and subcellular localization of the APX genes suggest the degree of complementation and coordination of the antioxidant defences in different cellular compartments during development and abiotic stress (Teixeira et al. 2004, 2006).

APX is highly responsive to various abiotic stresses and plays an important role in the scavenging of ROS in plants. Mutant studies in Arabidopsis revealed that cytosolic APXs (APX1 and APX2) are critical for cellular $\mathrm{H}_{2} \mathrm{O}_{2}$ homeostasis and play an important role in growth, development and oxidative protection of chloroplasts under various abiotic stresses (Pnueli et al. 2003; Davletova et al. 2005; Koussevitzky et al. 2008; Zhang et al. 2013). In particular, Arabidopsis APX1 is important for plant growth and development (Pnueli et al. 2003), whereas APX2 is critical for drought tolerance (Rossel et al. 2006). Thylakoid-bound APXs (tAPXs) are crucial for photosynthesis and photoprotection under photo-oxidative stress in Arabidopsis (Kangasjarvi et al. 2008). In rice, expressions of OSAPX genes are modulated by various abiotic stresses and exogenous ABA as well as by biotic stresses (Agrawal et al. 2003; Teixeira et al. 2006; Hong et al. 2007; Rosa et al. 2010). The expressions of two cytosolic APX genes, OsAPX1 and OsAPX2, are developmentally regulated (Agrawal et al. 2003) and the suppression of either of these genes resulted in strong effects on plant growth and development and produced semi-dwarf rice phenotypes (Rosa et al. 2010). Zhang et al. (2013), reported similar results wherein, downregulation of OsAPX2 gene affected the growth and development of rice seedlings, resulting in semi-dwarf and lesion-mimic seedlings, yellow-green leaves, and seed sterility. In contrast, the overexpression of OsAPX2 gene increased APX enzyme activity and thus resulted in enhanced stress tolerance.

Davletova et al. (2005), demonstrated the role of cytosolic APX1 in cross-compartment protection of thylakoid/stromal and mitochondrial APXs during light stress. Despite the protection of each individual cellular compartment by its own set of ROS-scavenging enzymes, APX1-deficient Arabidopsis plants exhibited the oxidation of chloroplastic, mitochondrial and membrane-bound proteins, suggesting the key role of cytosolic APX1 enzyme in the cross-compartment protection of adjacent compartments (Davletova et al. 2005). However, some early studies certainly suggest that thylakoid membrane- bound APX (tAPX) is a limiting factor of antioxidative systems under photo-oxidative stress in chloroplasts and that the enhanced activity of tAPX under stress is to maintain the redox status of ascorbate (Yabuta et al. 2002). Moreover, transgenic Arabidopsis plants overexpressing Suaeda salsa chloroplastic stromal APX (sAPX) and thylakoid-bound APX (tAPX) also showed an increased tolerance to high light oxidative stress by efficient detoxification of ROS (Pang et al. 2011).

Ascorbate also plays a significant role in formation of zeaxanthin during photo-oxidative stress (Figure 2). The excess excitation energy from the incidence of high light is invariably dissipated as heat by zeaxanthin in the light harvesting complex of the photosynthetic apparatus (Demmig-Adams and Adams 1996). Zeaxanthin is regenerated (via Xanthophyll cycle) in the successive deepoxidation of violaxanthin and antheroxanthin by the enzyme VDE, which is located in the thylakoid lumen, and requires ascorbate as a cofactor (Neubauer and Yamamoto 1993; Müller-Moulé et al. 2002). MüllerMoulé et al. (2003), demonstrated the role of ascorbate in regeneration of zeaxanthin in ascorbate-deficient mutant of Arabidopsis, vtc2. These plants are characterized with an increased degree of lipid peroxidation and photoinhibition, and the regeneration of zeaxanthin from violaxanthin was slower due to insufficient ascorbate content.

\section{Role of I-ascorbate in salinity and drought tolerance}

In the cell, ROS is continuously produced during normal functioning of the photosynthesis, respiration and photorespiration as well as in various enzyme-catalyzed redox reactions (Dat et al. 2000; Moller 2001). However, ROS activity increases several folds under stress conditions and can serve as a signal that activates defense responses by specific signal transduction pathway in which hydrogen peroxide acts as secondary messenger (Helena and de Carvalho 2008). However, an increased ROS activity for the prolonged period can cause oxidative stress in plants. If ROS is not efficiently scavenged and quenched, it can cause membrane lipid peroxidation, inactivation of cellular enzymes and degradation of nucleic acids, which may eventually lead to the death of plant cells.

Plants with higher ascorbate content can effectively scavenge the excessive ROS generated during stress conditions, and confer increased tolerance to abiotic stresses. Increased salt stress sensitivity of the Arabidopsis vtc mutant is attributed to the low intrinsic ascorbate levels and impaired ascorbate-glutathione cycle, which resulted in an enhanced ROS activity and a significant decrease in the $\mathrm{CO}_{2}$ assimilatory capacity (Huang et al. 2005). Moreover, deficiency of ascorbate may limit the 
recycling of $\alpha$-tocopheroxyl radicals to $\alpha$-tocopherol, which may, in turn, increase the oxidation of thylakoid membrane lipids under drought conditions (MunnéBosch and Alegre 2002). Several transgenic plants overproducing ascorbate showed an enhanced salt and drought tolerance with reduced membrane lipid peroxidation and chlorophyll content loss. These plants also exhibited higher survival rate and a significantly higher seed germination rate, fresh weight and root length (Wang et al. 2005; Sun et al. 2010a; Zhang et al. 2011). Transgenic potato plants expressing strawberry GalUR gene and rat GLOase gene with several-fold increased biosynthesis of ascorbate also exhibited a better survival under salinity and drought stresses conditions including a reduction in the level of lipid peroxidation (Hemavathi et al. 2009; Hemavathi et al. 2011; Upadhyaya et al. 2011).

Regulation of plant ascorbate redox state by means of synthesis, degradation and transport plays an essential role in plant adaptation to the stress (Stevens et al. 2008; Yin et al. 2010). MDAR and DHAR are key enzymes involved in the regulation of the ascorbate redox state and are of vital importance in the oxidative stress tolerance. MDAR maintains higher redox state of ascorbate by recycling the oxidized MDHA. Several isoforms of MDAR have been found in different cellular compartments, such as chloroplasts (Miyake and Asada 1994; Sano et al. 2005), cytosol and mitochondria (De Leonardis et al. 1995; Jiménez et al. 1997; Mittova et al. 2003), peroxisomes (Mittova et al. 2003; Leterrier et al. 2005) and glyoxysomes (Bowditch and Donaldson 1990), to serve the specific physiological role in each cellular compartment. The level of MDAR expression increases in response to oxidative stress triggered by several stress conditions (Yoon et al. 2004; Leterrier et al. 2005; Kavitha et al. 2010). Transgenic tobacco plants overexpressing a salt-inducible chloroplastic MDAR from halophyte Avicennia marina survived better under conditions of salt stress compared with wild-type plants (Kavitha et al. 2010). Similarly, transgenic potato plants overexpressing the Arabidopsis DHAR gene in the cytosol exhibited enhanced DHAR activity with faster growth, even under drought and salt stress conditions (Eltayeb et al. 2011).

High salt and drought tolerances were also observed in transgenic plants overexpressing $A P X$ gene. Heterologous expression of OsAPX2 gene improved salt tolerance in transgenic Arabidopsis and alfalfa ( $\mathrm{Lu}$ et al. 2007; Guan et al. 2012). Increased APX activity was observed in roots of etiolated rice seedlings in response to $\mathrm{NaCl}$ stress and was correlated with upregulation of chloroplastic OsAPX8 expression; however, no effect on the expression of the rest of the rice APX isoforms was observed (Hong et al. 2007). In contrast, Teixeira et al.
(2006), reported the enhanced expression of OsAPX2 and OsAPX7, and severe downregulation of OsAPX8 in rice seedlings under $\mathrm{NaCl}$ stress. This observed discrepancy in the above results seemed to be differ with cultivars, plant age, tissues, and growing conditions (Hong et al. 2007).

It has been demonstrated that OsAPX gene expression and $\mathrm{H}_{2} \mathrm{O}_{2}$ production were increased in response to $\mathrm{NaCl}$ in roots of etiolated rice seedlings (Tsai et al. 2004, 2005). However, OsAPX8 expression and APX activity induced by $\mathrm{NaCl}$ are not mediated through $\mathrm{H}_{2} \mathrm{O}_{2}$ in rice roots (Tsai et al. 2005; Hong et al. 2007). In rice roots, accumulation of ABA in response to $\mathrm{NaCl}$ was correlated with upregulation of OsAPX8 expression (Hong et al. 2007). Moreover, exogenous application of ABA also specifically enhanced the expression of OsAPX8. Similarly, application of ABA increased the expression of APX genes in pea, rice, and sweet potato (Mittler and Zilinskas 1992; Agrawal et al. 2003; Park et al. 2004). These findings indicate that $\mathrm{NaCl}$ induced expression of APX is mediated through an accumulation of the ABA.

Transgenic plants overexpressing a heterologous cytosolic APX gene showed an enhanced tolerance to salt stress with lower ROS activity (Badawi et al. 2004; Wang et al. 2005; Lu et al. 2007; Faize et al. 2011). These transgenic plants exhibited lower electrolyte leakage and lipid peroxidation, higher water use efficiency, minimal leaf damage and better photosynthetic performance. Similar results were obtained in the transgenic tobacco overexpressing Solanum lycopersicum thylakoid-bound APX (tAPX) and showed a better performance in terms of photosynthetic efficiency, root lengths and fresh and dry weights of the plants with enhanced tolerance to salt and osmotic stresses (Sun et al. 2010a).

Yamamoto et al. (2005), demonstrated that downregulation of apoplastic AAO (ascorbate oxidase) confers higher salt tolerance in tobacco and Arabidopsis plants. It was suggested that under salt stress conditions, suppressed expression of apoplastic AAO led to a relatively low level of hydrogen peroxide accumulation and a high redox state of symplastic and apoplastic ascorbate, which, in turn, increased the salt tolerance. Interestingly, transgenic tobacco plants with elevated levels of hydrogen peroxide by overexpression of a cell wall-localized cucumber AAO conferred increased drought tolerance due to reduced stomatal conductance (Fotopoulos et al. 2008).

Control of the stomatal aperture is essential for the plant adaptation to changes in its ambient environment. Several mechanisms for the regulation of stomatal aperture have been proposed (Kim and Lee 2007; Araújo et al. 2011). It has been found that $\mathrm{O}_{2}^{-}$and other activated oxygen species are involved in the regulation of stomatal movement (Purohit et al. 1994). Zhang et al. 
(2001), demonstrated that hydrogen peroxide may function as an intermediate in ABA signalling in guard cells. During stress conditions ABA causes an increase in hydrogen peroxide production and induces stomatal closure. Stomatal closure induced by hydrogen peroxide was reversed by exogenous application of ascorbate because of hydrogen peroxide detoxification activity of ascorbate (Zhang et al. 2001). Earlier, Chen and Gallie (2004), demonstrated that transgenic plants with DHAR overexpression exhibited an increase in the ascorbate redox state and reduced levels of hydrogen peroxide in guard cells and leaves showed greater stomatal opening, increased transpiration rate and stomatal conductance even under normal growth conditions. Whereas, plants with suppression of DHAR activity showed an elevated level of hydrogen peroxide and conferred increased drought tolerance with a decreased ascorbate redox state.

It has been known that the enzyme AAO, which catalyzes the oxidation of ASA to DHA exclusively located in the apoplast, plays an important role in the maintenance of the redox state of the apoplastic ascorbate levels (Pignocchi and Foyer 2003; Sanmartin et al. 2003; Pignocchi et al. 2006). However, the mechanism of regulation of $A A O$ gene expression and stomatal moments is not clearly understood. It has been suggested that the signal perception of stomatal closure is altered by AAO overexpression (Pignocchi and Foyer 2003; Fotopoulos et al. 2008). Transgenic tobacco leaves overexpressing a cell wall-localized cucumber AAO contained elevated levels of hydrogen peroxide and ABA content, thereby resulting in reduced stomatal conductance and reduced rates of water loss (Fotopoulos et al. 2008). Based on these results, it is predictable that either the suppression of DHAR expression or the overexpression of AAO would result in the decrease in the ascorbate redox state and causes increased accumulation of hydrogen peroxide levels resulting in stomatal closure, lower transpiration thus providing drought tolerance. However, in both, suppression of DHAR expression or overexpression of AAO would result in greater accumulation of apolastic DHA levels which may play a key role in the regulation of stomatal aperture.

\section{Ascorbate as an ozone protectant}

An increasing concentration of ambient ozone was observed during recent decades in many industrial and rural regions of the world and poses a hazard for vegetation. The ozone exposure of plants causes extensive visible leaf damage and decreased rates of stomatal conductance and photosynthesis (Pell et al. 1997; Torsethaugen et al. 1997; Zheng et al. 2000; Sanmartin et al. 2003). Ozone entered through stomata reacts with apoplastic and symplastic components of the cell (Long and Naidu 2002; Castagna and Ranieri 2009; Cho et al. 2011) resulting in a greater accumulation of ROS, which causes an oxidative damage to the photosynthetic membranes and finally leads to the death of photosynthetic mesophyll cells (Godde and Buchhold 1992; Ciompi et al. 1997; Chen et al. 2005). It was suggested that ozone exposure directly affects guard cells by inhibiting the ion channels $\left(\mathrm{K}^{+1}\right.$ channel) activity in the guard cell plasma membrane (Torsethaugen et al. 1999). Protection of crop plants from ozone damage could be accomplished by replacement of sensitive biotypes with more tolerant ones as well as by application of synthetic ozone protectants such as ethylene diurea, azoxystrobin, epoxiconazole and penconazole (Blum et al. 2011; Didyk and Blum 2011). However, application of synthetic ozone protectants will pollute the environment and may affect the crop production. Therefore, it is necessary to develop alternative ecofriendly strategies to minimize the ozone damage in plants by using plant-based natural antioxidants such as ascorbic acid.

Apoplastic ascorbate is assumed to represent the first line of defence against potentially damaging pollutants (Plöchl et al. 2000; Barnes et al. 2002). Apoplastic ascorbate can protect plants from ozone-induced damage by directly reacting with ozone (Chameides 1989; Plöchl et al. 2000) and ROS (D'Haese et al. 2005) or by serving as a substrate in ROS-scavenging enzymatic reactions (Chen and Gallie 2005). Plant species that are resistant to ozone showed an increased apoplastic ascorbate levels (Lee 1991; Turcsányi et al. 2000; Zheng et al. 2000; Burkey et al. 2006; Feng et al. 2010). Moreover, exogenous application of plants with ascorbate prevented the foliar injury and alleviated the decline in photosynthesis rate caused by ozone stress (Maddison et al. 2002; Zheng et al. 2000). The lower levels of apoplastic ascorbate content greatly enhanced foliage injury upon chronic ozone exposure in tobacco (Sanmartin et al. 2003). Furthermore, Arabidopsis mutants (vtc1) with low foliar content of ascorbate exhibit hypersensitivity to ozone (Conklin and Barth 2004). Similarly, rice TOS17 insertional mutant (ND6172) for a GDP-D-mannose-3,5'epimerase gene, which is characterized with $20-30 \%$ lower ascorbate level than the wild type, showed a higher level of visible leaf damage upon ozone exposure (Frei et al. 2012).

Maintenance of the apoplastic ascorbate redox state is crucial for ozone-induced oxidative stress tolerance of plants and is influenced by activities of enzymes such as AAO and APX. Altered expression of these enzymes was normally observed in plants exposed to ozone (Kubo et al. 1995; Sanmartin et al. 2003; Pignocchi et al. 2006). Transgenic tobacco plants with overexpressing AAO (Sanmartin et al. 2003) or downregulation of cytosolic APX (Orvar and Ellis 1997) resulted in the 
increased susceptibility of tobacco plants to ozoneinduced damage. However, transgenic tobacco plants overproducing chloroplastic APX could not protect from ozone injury (Torsethaugen et al. 1997). The apoplastic ascorbate redox state also depends on the balance between oxidation of ascorbate to DHA in apoplast and reduction of MDA and DHA to ascorbate in cytoplasm. During the detoxification process, DHA produced in the apoplast diffuses into the cytoplasm and recycled back to ascorbate by cytDHAR (via ascorbate-glutathione cycle, Figure 2) on the plasma membrane. The regenerated ascorbate can be transported back into the apoplast for the detoxification of ozone (Luwe et al. 1993; Horemans et al. 2000a; Yoshida et al. 2006). Transgenic tobacco plants overexpressing MDAR gene conferred enhanced tolerance to ozone due to increased recycling of ascorbate from MDA (Eltayeb et al. 2007). Similarly, DHAR-overexpressing plants also showed an increased ozone tolerance with a higher level of photosynthetic activity despite exhibiting a larger stomatal area (Chen and Gallie 2005). In converse, plants with suppressed DHAR activity showed a substantially reduced stomatal area and lower level of photosynthetic activity. Yoshida et al. (2006), demonstrated that Arabidopsis mutant with completely lacking cytDHAR activity showed a significantly lower level of apoplastic ascorbate and was highly sensitive to ozone (Yoshida et al. 2006). Increased level of ascorbate through enhanced ascorbate recycling by DHAR overexpression offered greater protection against oxidative stress despite poor ability to respond to ozone through stomatal closure (Chen and Gallie 2005; Eltayeb et al. 2007).

\section{Role of ascorbate in temperature stress tolerance}

Temperature stress is one of the most important environmental factors affecting the crop yields and geographic distribution of plants. Temperature stresses such as heat, cold or freezing result in excessive ROS production and cause severe damage to cell membranes and proteins (O'Kane et al. 1996; Larkindale and Knight 2002; Suzuki and Mittler 2006; Hu et al. 2008; Yamashita et al. 2008) and also cause impairments in the chloroplast and mitochondrial metabolism (Salvucci and Crafts-Brandner 2004; Vacca et al. 2004; Barra et al. 2005; Nguyen et al. 2009; Barta et al. 2010; Tóth et al. 2011).

Several studies demonstrated that ROS-mitigating mechanisms play an important role in protecting crops against extreme temperature stresses (Iba 2002; Yoshimura et al. 2004; Hu et al. 2008). For instance, overexpression of cytosolic APX in transgenic tomato enhances heat and chilling stress tolerance (Wang et al. 2005, 2006). Similarly, transgenic potato plants overexpressing APX under the control of an oxidative stress inducible SWPA2 promoter showed increased tolerance to high temperature stress (Tang et al. 2006). In rice, overexpression of OsAPX1 enhanced tolerance to chilling stress at the booting stage (Sato et al. 2011). Increased temperature stress tolerance was also observed in transgenic tobacco plants overexpressing the thylakoid-bound $A P X$ gene from tomato. These transgenic tobacco lines, under stress condition, showed a higher APX activity and contained less hydrogen peroxide and malondialdehyde than wild-type plants (Sun et al. 2010b). Moreover, under chilling and heat stresses, the photochemical efficiency of PSII in the transgenic lines was distinctly higher than that of wild-type plants. Wang et al. (2011), reported the similar results in transgenic tobacco plants overproducing ascorbate through the expression of tomato GMPase and observed the reduced ROS activity in the transgenic plants under high or low temperature stress conditions.

L-ascorbate may also act as an alternative electron donor of PSII; in those cases electron transfer is inhibited due to inactivation of oxygen evolving complex (OEC) (Mano et al. 2004; Guiss'e et al. 1995; Strasser 1997; Tóth et al. 2009; Gururani et al. 2012). Heatinduced inactivation of PSII was strongly influenced by the ascorbate content of leaves (Tóth et al. 2011). Tóth et al. (2011), experimentally proved the physiological role of ascorbate as alternative PSII electron donor in heat-stressed leaves with inactive OEC. This result suggests that the role of ascorbate as an alternative PSII electron donor is to decelerate the processes of photoinactivation and minimize the ROS activity in the photosynthetic thylakoid membranes, and thus minimize the damage to the entire photosynthetic apparatus.

\section{Conclusion}

In higher plants, ascorbate biosynthesis occurs through D-mannose/L-galactose pathway, which is a most important source of ascorbate. Ascorbate plays a major role in cellular ROS-scavenging activity. It also influences many stress responsive enzyme activities through synergic action with the other antioxidants such as glutathione and $\alpha$-tocopherol and reduces the oxidative damage to cells. Recent studies suggest its role in photosynthesis as an alternative electron donor to PSII under abiotic stress conditions and play a major role in protection of photosynthetic apparatus in chloroplast by keeping the ROS activity under check.

Several ascorbate biosynthetic pathway transgenes have been introduced into plants through genetic engineering to elevate the ascorbate level. These transgenic plants also provided better stress tolerance to various abiotic stresses such as high light, low/high temperature, ozone, salinity and drought. The role of ascorbate goes beyond that of simply an antioxidant given its apparent 
involvement in a complex signalling pathway that mediates responses to biotic and abiotic stresses as it is a cofactor for plant hormones such as ABA, GA and ethylene (Conklin and Barth 2004). However, role of ascorbate in signal transduction needs to be clarified further, particularly with respect to drought tolerance provided by altered stomatal movements.

\section{Abbreviations}

ABA: Abscisic acid; AGC: The ascorbate-glutathione cycle; AAO: Ascorbate oxidase; APX: Ascorbate peroxidase; DHA: Dehydroascorbate;

DHAR: Dehydroascorbate reductase; GA: Gibberellic acid; GalUR: D-galacturonic acid reductase; GLOase: L-gulono-c-lactone oxidase; GR: Glutathione reductase; GSH: Glutathione; GSSG: Glutathione disulfide; MDAR: Monodehydroascorbate reductase; MDHA: Monodehydroascorbate; MIOX: Myoinositol oxygenase; L-GalLDH: L-galactono-1,4-lactone dehydrogenase; OEC: Oxygen evolving complex; PSI: Photosystem l; PSII: Photosystem II; SOD: Superoxide dismutase; ROS: Reactive oxygen species; VDE: Violaxanthin de-epoxidase; WWC: The water-water cycle.

\section{Competing interests}

The authors declare that they have no competing interests.

\section{Authors' contributions}

JV surveyed the literature and drafted the manuscript. PSW provided guidelines for the review, modified and prepared the final version of the manuscript. All authors read and approved the final manuscript.

\section{Acknowledgements}

This paper resulted from the Konkuk University research support program.

Received: 8 October 2012 Accepted: 16 December 2013

Published: 9 April 2014

\section{References}

Agius F, Lamothe RG, Caballero JL, Blanco JM, Botella MA, Valpuesta V (2003) Engineering increased vitamin C levels in plants by over-expression of a D-galacturonic acid reductase. Nat Biotechnol 21:177-181

Agrawal GK, Jwa NS, Iwahashi H, Rakwal R (2003) Importance of ascorbate peroxidases OsAPX1 and OsAPX2 in the rice pathogen response pathways and growth and reproduction revealed by their transcriptional profiling. Gene 322:93-103

Alhagdow M, Mounet F, Gilbert L, Nunes-Nesi A, Garcia V, Just D, Petit J, Beauvoit $B$, Fernie AR, Rothan C, Baldet P (2007) Silencing of the mitochondrial ascorbate synthesizing enzyme L-galactono-1,4-lactone dehydrogenase affects plant and fruit development in tomato. Plant Physiol 145:1408-1422

Araújo WL, Fernie AR, Nunes-Nesi A (2011) Control of stomatal aperture: a renaissance of the old guard. Plant Signal Behav 6:1305-1311

Asada K (1994) Mechanisms for Scavenging Reactive Molecules Generated in Chloroplasts Under Light Stress. In: Baker NR, Bowyer JR (eds) Photoinhibition of Photosynthesis. From Molecular Mechanisms to the Field. Bios Scientific Publishers, Oxford, pp 129-142

Asada K (1999) The water-water cycle in chloroplasts: scavenging of active oxygens and dissipation of excess photons. Annu Rev Plant Physiol Plant Mol Biol 50:601-639

Asada K (2006) Production and scavenging of reactive oxygen species in chloroplasts and their functions. Plant Physiol 141:391-396

Asada K, Takahashi M (1987) Production and Scavenging of Active Oxygen in Photosynthesis. In: Kyle DJ, Osmond CB, Arntzen CJ (eds) Photoinhibition. Elsevier, Amsterdam, pp 227-287

Asard H, Kapila J, Verelst W, Berczi A (2001) Higher-plant plasma membrane cytochrome b561: a protein in search of a function. Protoplasma 217:77-93

Badawi GH, Kawano N, Yamauchi Y, Shimada E, Sasaki R, Kubo A, Tanaka K (2004) Over-expression of ascorbate peroxidase in tobacco chloroplasts enhances the tolerance to salt stress and water deficit. Physiol Plant 121:231-238

Badejo AA, Eltelib HA, Fukunaga K, Fujikawa Y, Esaka M (2009) Increase in ascorbate content of transgenic tobacco plants overexpressing the acerola (Malpighia glabra) phosphomannomutase gene. Plant Cell Physiol 50:423-428
Badejo AA, Wada K, Gao Y, Maruta T, Sawa Y, Shigeoka S, Ishikawa T (2012) Translocation and the alternative D-galacturonate pathway contribute to increasing the ascorbate level in ripening tomato fruits together with the D-mannose/L-galactose pathway. J Exp Bot 63:229-239

Barnes JD, Zheng Y, Lyons TM (2002) Plant Resistance to Ozone: The Role of Ascorbate. In: Omasa K, Saji H, Youssefian S, Kondo N (eds) Air Pollution and Plant Biotechnology. Springer-Verlag, Tokyo, pp 235-254

Barra M, Haumann M, Dau H (2005) Specific loss of the extrinsic 18 KDa protein from photosystem II upon heating to $47^{\circ} \mathrm{C}$ causes inactivation of oxygen evolution likely due to Ca release from the Mn-complex. Photosynth Res 84:231-237

Barta C, Dunkle AM, Wachter RM, Salvucci ME (2010) Structural changes associated with the acute thermal instability of Rubisco activase. Arch Biochem Biophys 499:17-25

Blum O, Didyk N, Pavluchenko N, Godzik B (2011) Assessment of protective effect of some modern agrochemicals against ozone-induced stress in sensitive clover and tobacco cultivars. J Toxicol, doi:10.1155/2011/308598

Bowditch MI, Donaldson RP (1990) Ascorbate free-radical reduction by glyoxysomal membranes. Plant Physiol 94:531-537

Bulley S, Wright M, Rommens C, Yan H, Rassam M, Lin-Wang K, Andre C, Brewster D, Karunairetnam S, Allan AC, Laing WA (2012) Enhancing ascorbate in fruits and tubers through over-expression of the L-galactose pathway gene GDP-Lgalactose phosphorylase. Plant Biotechnol J 10:390-397

Burkey KO, Neufeld HS, Souza L, Chappelka AH, Davison AW (2006) Seasonal profiles of leaf ascorbic acid content and redox state in ozone-sensitive wildflowers. Environ Pollut 143:427-434

Castagna A, Ranieri A (2009) Detoxification and repair process of ozone injury: from O3 uptake to gene expression adjustment. Environ Pollut 157:1461-1469

Chameides WL (1989) The chemistry of ozone deposition to plant leaves: role of ascorbic acid. Environ Sci Technol 23:595-600

Chen Z, Gallie DR (2004) The ascorbic acid redox state controls guard cell signaling and stomatal movement. Plant Cell 16:1143-1162

Chen Z, Gallie DR (2005) Increasing tolerance to ozone by elevating foliar ascorbic acid confers greater protection against ozone than increasing avoidance. Plant Physiol 138:1673-1689

Chen Z, Young TE, Ling J, Chang SC, Gallie DR (2003) Increasing vitamin C content of plants through enhanced ascorbate recycling. Proc Natl Acad Sci U S A 100:3525-3530

Chew O, Whelan J, Millar H (2003) Molecular definition of the ascorbateglutathione cycle in Arabidopsis mitochondria reveals dual targeting of antioxidant defenses in plants. J Biol Chem 278:46869-46877

Cho K, Tiwari S, Agrawal SB, Torres NL, Agrawal M, Sarkar A, Shibato J, Agrawal GK, Kubo A, Rakwal R (2011) Tropospheric ozone and plants: absorption, responses and consequences. Rev Environ Contam Toxicol 212:61-111

Ciompi S, Castagna A, Ranieri A, Nali C, Lorenzini G, Soldatini GF (1997) $\mathrm{CO}_{2}$ assimilation, xanthophyll cycle pigments and PSIl efficiency in pumpkin plants as affected by ozone fumigation. Physiol Plant 101:881-889

Conklin PL, Barth C (2004) Ascorbic acid, a familiar small molecule intertwined in the response of plants to ozone, pathogens, and the onset of senescence. Plant Cell Environ 27:959-970

Conklin PL, Williams EH, Last RL (1996) Environmental stress sensitivity of an ascorbic acid-deficient Arabidopsis mutant. Proc Natl Acad Sci U S A 93:9970-9974

Conklin PL, Norris SN, Wheeler GL, Smirnoff N, Williams EH, Smirnoff N, Last RL (1999) Genetic evidence for the role of GDP-mannose in plant ascorbic acid (vitamin C) biosynthesis. Proc Natl Acad Sci U S A 96:4198-4203

Conklin PL, Saracco SA, Norris SR, Last RL (2000) Identification of ascorbic aciddeficient Arabidopsis thaliana mutants. Genetics 154:847-856

Conklin PL, Gatzek S, Wheeler GL, Dowdle J, Raymond MJ, Rolinski S, Isupov M, Littlechild JA, Smirnoff N (2006) Arabidopsis thaliana vtc4 encodes Lgalactose-1-P phosphatase, a plant ascorbic acid biosynthetic enzyme. J Biol Chem 281:15662-15670

Cruz-Rus E, Amaya I, Sánchez-Sevilla JF, Botella MA, Valpuesta V (2011) Regulation of L-ascorbic acid content in strawberny fruits. J Exp Bot 62:4191-4201

D'Arcy-Lameta A, Ferrari-lliou R, Contour-Ansel D, Pham-Thi AT, Zuily-Fodil Y (2006) Isolation and characterization of four ascorbate peroxidase cDNAs responsive to water deficit in cowpea leaves. Ann Bot 97:133-140

D'Haese D, Vandermeiren K, Asard H, Horemans N (2005) Other factors than apoplastic ascorbate contribute to the differential ozone tolerance of two clones of Trifolium repens L. Plant Cell Environ 28:623-632

Daruwala R, Song J, Koh WS, Rumsey SC, Levine M (1999) Cloning and functional characterization of the human sodium-dependent vitamin C transporters hSVCT1 and hSVCT2. FEBS Lett 460:480-484 
Dat J, Vandenabeele S, Vranová E, Van Montagu M, Inzé D, Van Breusegem F (2000) Dual action of the active oxygen species during plant stress responses. Cell Mol Life Sci 57:779-795

Davey MW, Gilot C, Persiau G, Østergaard J, Han Y, Bauw GC, Van Montagu MC (1999) Ascorbate biosynthesis in Arabidopsis cell suspension culture. Plant Physiol 121:535-543

Davey MW, Van Montagu M, Inze D, Sanmartin M, Kanellis A, Smirnoff N, Benzie IJJ, Strain JJ, Favell D, Fletcher J (2000) Plant I-ascorbic acid: chemistry, function, metabolism, bioavailability and effects of processing. J Sci Food Agric 80:825-860

Davletova S, Rizhsky L, Liang H, Shengqiang Z, Oliver DJ, Coutu J, Shulaev V, Schlauch K, Mittler R (2005) Cytosolic ascorbate peroxidase 1 is a central component of the reactive oxygen gene network of Arabidopsis. Plant Cell 17:268-281

De Leonardis S, De Lorenzo G, Borraccino G, Dipierro S (1995) A specific ascorbate free radical reductase isozyme participates in the regeneration of ascorbate for scavenging toxic oxygen species in potato tuber mitochondria. Plant Physiol 109:847-851

Demmig-Adams B, Adams WW III (1996) Xanthophyll cycle and light stress in nature: uniform response to excess direct sunlight among higher plant species. Planta 198:460-470

Didyk NP, Blum OB (2011) Natural antioxidants of plant origin against ozone damage of sensitive crops. Acta Physiol Plant 33:25-34

Do Nascimento J, Higuchi B, Gómez M, Oshiro R, Lajolo F (2005) L-Ascorbate biosynthesis in strawberries: L-galactono-1,4-lactone dehydrogenase expression during fruit development and ripening. Postharvest Biol Tech 38:34-42

Dowdle J, Ishikawa T, Gatzek S, Rolinski S, Smirnoff N (2007) Two genes in Arabidopsis thaliana encoding GDP-L-galactose phosphorylase are required for ascorbate biosynthesis and seedling viability. Plant J 52:673-689

Duan J, Zhang M, Zhang H, Xiong H, Liu P, Ali J, Li J, Li Z (2012a) OsMIOX, a myoinositol oxygenase gene, improves drought tolerance through scavenging of reactive oxygen species in rice (Oryza sativa L.). Plant Sci 196:143-151

Duan M, Ma NN, Li D, Deng YS, Kong FY, Lv W, Meng QW (2012b) Antisensemediated suppression of tomato thylakoidal ascorbate peroxidase influences anti-oxidant network during chilling stress. Plant Physiol Biochem 58:37-45

Eltayeb AE, Kawano N, Badawi GH, Kaminaka H, Sanekata T, Morishima I, Shibahara T, Inanaga S, Tanaka K (2006) Enhanced tolerance to ozone and drought stresses in transgenic tobacco overexpressing dehydroascorbate reductase in cytosol. Physiol Plant 127:57-65

Eltayeb AE, Kawano N, Badawi GH, Kaminaka H, Sanekata T, Shibahara T, Inanaga S, Tanaka K (2007) Overexpression of monodehydroascorbate reductase in transgenic tobacco confers enhanced tolerance to ozone, salt and polyethylene glycol stresses. Planta 225:1255-1264

Eltayeb AE, Yamamoto S, Habora MEE, Yin L, Tsujimoto H, Tanaka K (2011) Transgenic potato overexpressing Arabidopsis cytosolic AtDHAR1 showed higher tolerance to herbicide, drought and salt stresses. Breed Sci 61:3-10

Endres S, Tenhaken R (2009) Myoinositol oxygenase controls the level of myoinositol in Arabidopsis, but does not increase ascorbic acid. Plant Physiol 149:1042-1049

Eskling M, Arvidsson PO, Akerlund HE (1997) The xanthophyll cycle, its regulation and components. Physiol Plant 100:806-816

Faize M, Burgos L, Faize L, Piqueras A, Nicolas E, Barba-Espin G, Clemente-Moreno MJ, Alcobendas R, Artlip T, Hernandez JA (2011) Involvement of cytosolic ascorbate peroxidase and $\mathrm{Cu} / \mathrm{Zn}$-superoxide dismutase for improved tolerance against drought stress. J Exp Bot 62:2599-2613

Feng Z, Pang J, Nouchi I, Kobayashi K, Yamakawa T, Zhu J (2010) Apoplastic ascorbate contributes to the differential ozone sensitivity in two varieties of winter wheat under fully open-air field conditions. Environ Pollut 158:3539-3545

Fotopoulos V, De Tullio MC, Barnes J, Kanellis AK (2008) Altered stomatal dynamics in ascorbate oxidase over-expressing tobacco plants suggest a role for dehydroascorbate signalling. J Exp Bot 59:729-737

Foyer CH (2004) The Role of Ascorbic Acid in Defence Networks and Signalling in Plants. In: Asard H, May JM, Smirnoff N (eds) Vitamin C. Functions and Biochemistry in Animals and Plants. Bios Scientific Publishers, Oxford, UK, pp 65-82

Franceschi VR, Tarlyn NM (2002) L-ascorbic acid is accumulated in source leaf phloem and transported to sink tissues in plants. Plant Physiol 130:649-656

Frei M, Wissuwa M, Pariasca-Tanaka J, Chen CP, Südekum KH, Kohno Y (2012) Leaf ascorbic acid level- Is it important for ozone tolerance in rice? Plant Physiol Biochem 59:63-70

Gao Q, Zhang L (2008) Ultraviolet-B-induced oxidative stress and antioxidant defense system responses in ascorbate-deficient vtc1 mutants of Arabidopsis thaliana. J Plant Physiol 165:138-148
Gatzek S, Wheeler GL, Smirnoff N (2002) Antisense suppression of L-galactose dehydrogenase in Arabidopsis thaliana provides evidence for its role in ascorbate synthesis and reveals light modulated L-galactose synthesis. Plant J 30:541-553

Gest N, Gautier H, Stevens R (2013) Ascorbate as seen through plant evolution: the rise of a successful molecule? J Exp Bot 64:33-53

Godde D, Buchhold J (1992) Effect of long-term fumigation with ozone on the turnover of the D1 reaction centre polypeptide of photosystem II in spruce (Picea abies). Physiol Plant 86:568-574

Goo YM, Hyun JC, Kim TW, Lee CH, Ahn MJ, Bae SC, Cho KJ, Chun JA, Chung CH, Lee SW (2008) Expressional characterization of dehydroascorbate reductase cDNA in transgenic potato plants. J Plant Biol 51:35-41

Green MA, Fry SC (2005) Vitamin C degradation in plant cells via enzymatic hydrolysis of 4-O-oxalyl-L-threonate. Nature 433:83-87

Guan Q, Takano T, Liu S (2012) Genetic transformation and analysis of rice OsAPX2 gene in Medicago sativa. PLoS One 7:e41233

Guiss'e B, Srivastava A, Strasser RJ (1995) The polyphasicrise of the chlorophyll a fluorescence (O-K-J-I-P) in heat stressed leaves. Arch Sci Gen'eve 48:147-160

Gururani MA, Upadhyaya CP, Strasser RJ, Woong YJ, Park SW (2012) Physiological and biochemical responses of transgenic potato plants with altered expression of PSII manganese stabilizing protein. Plant Physiol Biochem 58:182-194

Hancock RD, McRae D, Haupt S, Viola R (2003) Synthesis of L-ascorbic acid in the phloem. BMC Plant Biol 3:7

Hancock RD, Walker PG, Pont SDA, Marquis N, Vivera S, Gordon SL, Brennan RM, Viola R (2007) L-ascorbic acid accumulation in fruit of Ribes nigrum occurs by in situ biosynthesis via the I-galactose pathway. Funct Plant Biol 34:1080-1091

Haroldsen VM, Chi-Ham CL, Kulkarni S, Lorence A, Bennett AB (2011) Constitutively expressed DHAR and MDHAR influence fruit, but not foliar ascorbate levels in tomato. Plant Physiol Biochem 49:1244-1249

Helena M, de Carvalho C (2008) Drought stress and reactive oxygen species. Production, scavenging and signaling. Plant Signal. Behav 3:156-165

Hemavathi CP, Upadhyaya KE, Young N, Akula HS, Kim JJ, Heung MH, Oh AC, Reddy SC, Chun DHK, Park SW (2009) Over-expression of strawberry D-galacturonic acid reductase in potato leads to accumulation of vitamin C with enhanced abiotic stress tolerance. Plant Sci 177:659-667

Hemavathi CP, Upadhyaya KE, Young N, Akula KE, Young SC, Chun DHK, Park SW (2010) Enhanced ascorbic acid accumulation in transgenic potato confers tolerance to various abiotic stresses. Biotechnol Lett 32:321-330

Hemavathi CP, Upadhyaya N, Akula HS, Kim JH, Jeon MH, Oh SC, Chun DHK, Park SW (2011) Biochemical analysis of enhanced tolerance in transgenic potato plants overexpressing $\mathrm{d}$-galacturonicacidreductase gene in response to various abiotic stresses. Mol Breed 28:105-115

Hong CY, Hsu YT, Tsai YC, Kao CH (2007) Expression of ascorbate peroxidase 8 in roots of rice (Oryza sativa L.) seedlings in response to NaCl. J Exp Bot 58:3273-3283

Horemans N, Asard H, Van Gestelen P, Caubergs RJ (1998) Facilitated diffusion drives transport of oxidised ascorbate molecules into purified plasma membrane vesicles of Phaseolus vulgaris. Physiol Plant 104:783-789

Horemans N, Foyer CH, Asard H (2000a) Transport and action of ascorbate at the plasma membrane. Trends Plant Sci 5:263-267

Horemans N, Foyer CH, Potters G, Asard H (2000b) Ascorbate function and associated transport systems in plants. Plant Physiol Biochem 38:531-540

Hu WH, Song XS, Shi K, Xia XJ, Zhou YH, Yu JQ (2008) Changes in electron transport, superoxide dismutase and ascorbate peroxidase isoenzymes in chloroplasts and mitochondria of cucumber leaves as influenced by chilling. Photosynthetica 46:581-588

Huang C, He W, Guo J, Chang X, Su P, Zhang L (2005) Increased sensitivity to salt stress in an ascorbate-deficient Arabidopsis mutant. J Exp Bot 56:3041-3049

Huang GJ, Chen HJ, Chang YS, Lu TL, Lin YH (2008) Sweet potato storage root thioredoxin $\mathrm{h} 2$ with both dehydroascorbate reductase and monodehydroascorbate reductase activities. Bot Stud 49:1-7

Iba K (2002) Acclimative response to temperature stress in higher plants: approaches of gene engineering for temperature tolerance. Annu Rev Plant Biol 53:225-245

Imai T, Karita S, Shiratori G, Hattori M, Nunome T, Oba K, Hirai M (1998) L-galactono- $\gamma$-lactone dehydrogenase from sweet potato: purification and CDNA sequence analysis. Plant Cell Physiol 39:1350-1358

Inzé D, Van Montagu M (1995) Oxidative stress in plants. Curr Opin Biotechnol 6:153-158

Ishikawa T, Sakai K, Takeda T, Shigeoka S (1995) Cloning and expression of CDNA encoding a new type of ascorbate peroxidase from spinach. FEBS Lett 367:28-32

Ishikawa T, Sakai K, Yoshimura K, Takeda T, Shigeoka S (1996) cDNAs encoding spinach stromal and thylakoid bound ascorbate peroxidase, differing in the presence or absence of their 3'-coding regions. FEBS Lett 384:289-293 
Ishikawa T, Yoshimura K, Sakai K, Tamoi M, Takeda T, Shigeoka S (1998) Molecular characterization and physiological role of a glyoxysome-bound ascorbate peroxidase from spinach. Plant Cell Physiol 39:23-34

Ishikawa T, Morimoto Y, Madhusudhan R, Sawa Y, Shibata H, Yabuta Y, Nishizawa A, Shigeoka S (2005) Acclimation to diverse environmental stresses caused by a suppression of cytosolic ascorbate peroxidase in tobacco BY-2 cells. Plant Cell Physiol 46:1264-1271

Ishikawa T, Dowdle J, Smirnoff N (2006) Progress in manipulating ascorbic acid biosynthesis and accumulation in plants. Physiol Plant 126:343-355

Jain AK, Nessler CL (2000) Metabolic engineering of an alternative pathway for ascorbic acid biosynthesis in plants. Mol Breed 6:73-78

Jiménez A, Hernández JA, del Río LA, Sevilla F (1997) Evidence for the presence of the ascorbate-glutathione cycle in mitochondria and peroxisomes of pea leaves. Plant Physiol 114:275-284

Kangasjärvi S, Lepistö A, Hännikäinen K, Piippo M, Luomala EM, Aro EM, Rintamäki E (2008) Diverse roles for chloroplast stromal and thylakoidbound ascorbate peroxidases in plant stress responses. Biochem J 412:275-285

Kavitha K, Georg S, Venkataraman G, Parida A (2010) A salt-inducible chloroplastic monodehydroascorbate reductase from halophyte Avicennia marina confers salt stress tolerance on transgenic plants. Biochimie 92:1321-1329

Keller R, Renz FSA, Kossmann J (1999) Antisense inhibition of the GDP-mannose pyrophosphorylase reduces the ascorbate content in transgenic plants leading to developmental changes during senescence. Plant J 19:131-141

Kim DJ, Lee JS (2007) Current theories for mechanism of stomatal opening: Influence of blue light, mesophyll cells, and sucrose. J Plant Biol 50:523-526

Koussevitzky S, Suzuki N, Huntington S, Armijo L, Sha W, Cortes D, Shulaev V, Mittler R (2008) Ascorbate peroxidase 1 plays a key role in the response of Arabidopsis thaliana to stress combination. J Biol Chem 283:34197-34203

Kubo A, Saji H, Tanaka K, Kondo N (1995) Expression of Arabidopsis cytosolic ascorbate peroxidase gene in response to ozone or sulfur dioxide. Plant Mol Biol 29:479-489

Kwon SY, Choi SM, Ahn YO, Lee HS, Lee HB, Park YM, Kwak SS (2003) Enhanced stress-tolerance of transgenic plants expressing a human dehydroascorbate reductase gene. J Plant Physiol 160:347-353

Laing WA, Bulley S, Wright M, Cooney J, Jensen D, Barraclough D, MacRae E (2004a) A highly specific l-galactose-1-phosphate phosphatase on the path to ascorbate biosynthesis. Proc Natl Acad Sci U S A 101:16976-16981

Laing WA, Frearson N, Bulley S, MacRae E (2004b) Kiwifruit I-galactose dehydrogenase: molecular, biochemical and physiological aspects of the enzyme. Funct Plant Biol 31:1015-1025

Laing WA, Wright MA, Cooney J, Bulley SM (2007) The missing step of the I-galactose pathway of ascorbate biosynthesis in plants, an l-galactose guanyltransferase, increases leaf ascorbate content. Proc Natl Acad Sci U S A 104:9534-9539

Larkindale J, Knight MR (2002) Protection against heat stress-induced oxidative damage in Arabidopsis involves calcium, abscisic acid, ethylene, and salicylic acid. Plant Physiol 128:682-695

Larkindale J, Hall JD, Knightand MR, Vierling E (2005) Heat stress phenotypes of Arabidopsis mutants implicate multiple signaling pathways in the acquisition of thermotolerance. Plant Physiol 138:882-897

Lazzarotto F, Teixeira FK, Rosa SB, Dunand C, Fernandes CL, Fontenele Ade V, Silveira JA, Verli H, Margis R, Margis-Pinheiro M (2011) Ascorbate peroxidase-related $(A P x-R)$ is a new heme-containing protein functionally associated with ascorbate peroxidase but evolutionarily divergent. New Phytol 191:234-250

Le Martret B, Poage M, Shiel K, Nugent GD, Dix PJ (2011) Tobacco chloroplast transformants expressing genes encoding dehydroascorbate reductase, glutathione reductase, and glutathione-S-transferase, exhibit altered anti-oxidant metabolism and improved abiotic stress tolerance. Plant Biotechnol J 9:661-673

Lee EH (1991) Plant resistance mechanisms to air pollutants: rhythms in ascorbic acid production during growth under ozone stress. Chronobiol Int 8:93-102

Lee YP, Kim SH, Bang JW, Lee HS, Kwak SS, Kwon SY (2007) Enhanced tolerance to oxidative stress in transgenic tobacco plants expressing three antioxidant enzymes in chloroplasts. Plant Cell Rep 26:591-598

Leterrier M, Corpas FJ, Barroso JB, Sandalio L, del Río LA (2005) Peroxisomal monodehydroascorbate reductase genomic clone characterization and functional analysis under environmental stress conditions. Plant Physiol 138:2111-2123

Li Q, Schultes NP (2002) Arabidopsis thaliana locus At5g62890, a nucleobaseascorbate transporter family member, is preferentially expressed in carpe transmitting tract and tapetal cells. Plant Sci 163:233-240

Li F, Wu QY, Sun YL, Wang LY, Yang XH, Meng QW (2010) Overexpression of chloroplastic monodehydroascorbate reductase enhanced tolerance to temperature and methyl viologen-mediated oxidative stresses. Physiol Plant 139:421-434
Lim MY, Pulla RK, Park JM, Harn CH, Jeong BR (2012) Over-expression of I-gulono- $\gamma$ lactone oxidase (GLOase) gene leads to ascorbate accumulation with enhanced abiotic stress tolerance in tomato. In Vitro Cell Dev Biol Plant 48:453-461

Lin KH, Lo HF, Lin CH, Chan MT (2007) Cloning and expression analysis of ascorbate peroxidase gene from eggplant under flooding stress. Bot Stud 48:25-34

Linster CL, Clarke SG (2008) L-ascorbate biosynthesis in higher plants: the role of VTC2. Trends Plant Sci 13:567-573

Liso R, Calabrese G, Bitonti MB, Arrigoni O (1984) Relationship between ascorbic acid and cell division. Exp Cell Res 150:314-320

Liu YH, Yu L, Wang RZ (2011) Level of ascorbic acid in transgenic rice for I-galactono-1, 4-lactone dehydrogenase overexpressing or suppressed is associated with plant growth and seed set. Acta Physiol Plant 33:1353-1363

Liu W, An HM, Yang M (2013a) Overexpression of Rosa roxburghii I-galactono-1,4lactone dehydrogenase in tobacco plant enhances ascorbate accumulation and abiotic stress tolerance. Acta Physiol Plant, doi:10.1007/s11738-012-1204-7

Liu YH, Yu L, Tong J, Ding J, Wang R, Lu Y, Xiao L (2013b) Tiller number is altered in the ascorbic acid-deficient rice suppressed for I-galactono-1,4-lactone dehydrogenase. J Plant Physiol 170:389-396

Long SP, Naidu SL (2002) Effects of oxidants at the biochemical, cell and physiological levels, with particular reference to ozone. In: Bell JNB, Treshow M (eds) Air Pollution and Plant Life. John Wiley \& Sons Ltd., Chichester, pp 69-88

Lorence A, Chevone Bl, Mendes P, Nessler CL (2004) Myoinositol oxygenase offers a possible entry point into plant ascorbate biosynthesis. Plant Physio 134:1200-1205

Lu Z, Liu D, Liu S (2007) Two rice cytosolic ascorbate peroxidases differentially improve salt tolerance in transgenic Arabidopsis. Plant Cell Rep 26:1909-1917

Luwe MWF, Takahama U, Heber U (1993) Role of ascorbate in detoxifiying ozone in the apoplast of spinach (Spinacia oleracea L.) leaves. Plant Physiol 101:969-976

Maddison J, Lyons T, Plöchl M, Barnes J (2002) Hydroponically cultivated radish fed L-galactono-1,4-lactone exhibit increased tolerance to ozone. Planta 214:383-391

Mano J, Hideg E, Asada K (2004) Ascorbate in thylakoid lumen functions as an alternative electron donor to photosystem II and photosystem I. Arch Biochem Biophys 429:71-80

Maruta T, Yonemitsu M, Yabuta Y, Tamoi M, Ishikawa T, Shigeoka S (2008) Arabidopsis phosphomannose isomerase 1, but not phosphomannose isomerase 2, is essential for ascorbic acid biosynthesis. J Biol Chem 283:28842-28851

Maurino VG, Grube E, Zielinski J, Schild A, Fischer K, Flügge UI (2006) Identification and expression analysis of twelve members of the nucleobase-ascorbate transporter (NAT) gene family in Arabidopsis thaliana. Plant Cell Physiol 47:1381-1393

Mittler R (2002) Oxidative stress, antioxidants and stress tolerance. Trends Plant Sci 7:405-410

Mittler R, Zilinskas BA (1992) Molecular cloning and characterization of gene encoding pea cytosolic ascorbate peroxidase. J Biol Chem 267:21802-21807

Mittler R, Vanderauwera S, Gollery M, Van Breusegem F (2004) Reactive oxygen gene network of plants. Trends Plant Sci 9:490-498

Mittova V, Tal M, Volokita M, Guy M (2003) Upregulation of the leaf mitochondrial and peroxisomal antioxidative systems in response to salt-induced oxidative stress in the wild salt-tolerant tomato species Lycopersicon pennellii. Plant Cell Environ 6:845-856

Miyake C, Asada K (1992) Thylakoid-bound ascorbate peroxidase in spinach chloroplasts and photoreduction of its primary oxidation product monodehydroascorbate radicals in thylakoids. Plant Cell Physiol 33:541-553

Miyake C, Asada K (1994) Ferredoxin-dependent photoreduction of the monodehydroascorbate radical in spinach thylakoids. Plant Cell Physiol 35:539-549

Moller IM (2001) Plant mitochondria and oxidative stress: electron transport, NADPH turnover, and metabolism of reactive oxygen species. Annu Rev Plant Physiol Plant Mol Biol 52:561-591

Müller-Moulé P (2008) An expression analysis of the ascorbate biosynthesis enzyme VTC2. Plant Mol Biol 68:31-41

Müller-Moulé P, Conklin PL, Niyogi KK (2002) Ascorbate deficiency can limit violaxanthin de-epoxidase activity in vivo. Plant Physiol 128:970-977

Müller-Moulé P, Havaux M, Niyogi KK (2003) Zeaxanthin deficiency enhances the high light sensitivity of an ascorbate-deficient mutant of Arabidopsis. Plant Physiol 133:748-760

Müller-Moulé P, Golan T, Niyogi KK (2004) Ascorbate-deficient mutants of Arabidopsis grow in high light despite chronic photooxidative stress. Plant Physiol 134:1163-1172

Mullineaux P, Karpinski S (2002) Signal transduction in response to excess light: getting out of the chloroplast. Curr Opin Plant Biol 5:43-48 
Munné-Bosch S, Alegre L (2002) Interplay between ascorbic acid and lipophilic antioxidant defences in chloroplasts of water-stressed Arabidopsis plants. FEBS Lett 524:145-148

Najami N, Janda T, Barriah W, Kayam G, Tal M, Guy M, Volokita M (2008) Ascorbate peroxidase gene family in tomato: its identiWcation and characterization. Mol Genet Genomics 279:171-182

Naqvi S, Zhu C, Farre G, Ramessar K, Bassie L, Breitenbach J, Perez Conesa D, Ros G, Sandmann G, Capell T, Christou P (2009) Transgenic multivitamin corn through biofortification of endosperm with three vitamins representing three distinct metabolic pathways. Proc Natl Acad Sci U S A 106:7762-7767

Narendra S, Venkataramani S, Shen GX, Wang J, Pasapula V, Lin Y, Kornyeyev D, Holaday AS, Zhang H (2006) The Arabidopsis ascorbate peroxidase 3 is a peroxisomal membrane-bound antioxidant enzyme and is dispensable for Arabidopsis growth and development. J Exp Bot 57:3033-3042

Neubauer C, Yamamoto HY (1992) Mehler-peroxidase reaction mediates zeaxanthin formation and zeaxanthin-related fluorescence quenching in intact chloroplasts. Plant Physiol 99:1354-1361

Neubauer C, Yamamoto HY (1993) The role of ascorbate in the related ascorbate peroxidase, violaxanthin de-epoxidase and non-photochemical fluorescencequenching activities. In: Yamamoto HY, Smith CM (eds) Photosynthetic Responses to the Environment. American Society of Plant Physiologists Rockville, Maryland, pp 166-171

Nguyen HT, Leipner J, Stamp P, Guerra-Peraza O (2009) Low temperature stress in maize (Zea mays L.) induces genes involved in photosynthesis and signal transduction as studied by suppression subtractive hybridization. Plant Physiol. Biochem 47:116-122

Noctor G, Foyer CH (1998) Ascorbate and glutathione: keeping active oxygen under control. Annu Rev Plant Physiol Plant Mol Biol 49:249-279

O'Kane D, Gill V, Boyd P, Burdon R (1996) Chilling, oxidative stress and antioxidant responses in Arabidopsis thaliana callus. Planta 198:371-377

Orvar BL, Ellis BE (1997) Transgenic tobacco plants expressing antisense RNA for cytosolic ascorbate peroxidase show increased susceptibility to ozone injury. Plant J 11:1297-1305

Pallanca JE, Smirnoff N (2000) The control of ascorbic acid synthesis and turnover in pea seedlings. J Exp Bot 51:699-674

Panchuk II, Volkov RA, Schöz F (2002) Heat stress- and heat shock transcription factor-dependent expression and activity of ascorbate peroxidase in Arabidopsis. Plant Physiol 129:838-853

Pang CH, Li K, Wang B (2011) Overexpression of SSCHLAPXS confers protection against oxidative stress induced by high light in transgenic Arabidopsis thaliana. Physiol Plant 143:355-366

Park SY, Ryu SH, Jang LC, Kwon SY, Kim JG, Kwak SS (2004) Molecular cloning of a cytosolic ascorbate peroxidase CDNA from cell cultures of sweet potato and its expression in response to stress. Mol Gen Genomics 271:339-346

Parsons HT, Fry SC (2012) Oxidation of dehydroascorbic acid and 2,3diketogulonate under plant apoplastic conditions. Phytochemistry 75:41-49

Parsons HT, Yasmin T, Fry SC (2011) Alternative pathways of dehydroascorbic acid degradation in vitro and in plant cell cultures: novel insights into vitamin C catabolism. Biochem J 440:375-383

Pell EJ, Schlagnhaufer CD, Arteca RN (1997) Ozone-induced oxidative stress: mechanisms of action and reaction. Physiol Plant 100:264-273

Pignocchi C, Foyer CH (2003) Apoplastic ascorbate metabolism and its role in the regulation of cell signaling. Curr Opin Plant Biol 6:379-389

Pignocchi C, Fletcher JM, Wilkinson JE, Barnes JD, Foyer CH (2003) The function of ascorbate oxidase in tobacco. Plant Physiol 132:1631-1641

Pignocchi C, Kiddle G, Hernández I, Foster SJ, Asensi A, Taybi T, Barnes J, Foyer $\mathrm{CH}$ (2006) Ascorbate oxidase-dependent changes in the redox state of the apoplast modulate gene transcript accumulation leading to modified hormone signaling and orchestration of defense processes in tobacco. Plant Physiol 141:423-435

Plöchl M, Lyons T, Ollerenshaw J, Barnes J (2000) Simulating ozone detoxification in the leaf apoplast through the direct reaction with ascorbate. Planta 210:454-467

Pnueli L, Liang H, Rozenberg M, Mittler R (2003) Growth suppression, altered stomatal responses, and augmented induction of heat shock proteins in cytosolic ascorbate peroxidase (APX1)-deficient Arabidopsis plants. Plant J 34:187-203

Purohit S, Kumar GP, Laloraya M, Laloraya MM (1994) Involvement of superoxide radical in signal transduction regulating stomatal movements. Biochem Biophys Res Commun 205:30-37

Qian W, Yu C, Qin H, Liu X, Zhang A, Johansen IE, Wang D (2007) Molecular and functional analysis of phosphomannomutase (PMM) from higher plants and genetic evidence for the involvement of PMM in ascorbic acid biosynthesis in Arabidopsis and Nicotiana benthamiana. Plant J 49:399-413

Qin A, Shi Q, Yu X (2011) Ascorbic acid contents in transgenic potato plants overexpressing two dehydroascorbate reductase genes. Mol Biol Rep 38:1557-1566

Radzio JA, Lorence A, Chevone BI, Nessler CL (2003) L-Gulono-1,4-lactone oxidase expression rescues vitamin C-deficient Arabidopsis (vtc) mutants. Plant Mol Biol 53:837-844

Rosa SB, Caverzan A, Teixeira FK, Lazzarotto F, Silveira JA, Ferreira-Silva SL, Abreu-Neto J, Margis R, Margis-Pinheiro M (2010) Cytosolic APX knockdown indicates an ambiguous redox response in rice. Phytochemistry 71:548-558

Rossel JB, Walter PB, Hendrickson L, Chow WS, Poole A, Mullineaux PM, Pogson BJ (2006) A mutation affecting ascorbate peroxidase 2 gene expression reveals a link between responses to high light and drought tolerance. Plant Cell Environ 29:269-281

Salvucci ME, Crafts-Brandner SJ (2004) Relationship between the heat tolerance of photosynthesis and the thermal stability of Rubisco activase in plants from contrasting thermal environments. Plant Physiol 134:1460-1470

Sanmartin M, Drogoudi PA, Lyons T, Pateraki I, Barnes J, Kanellis AK (2003) Overexpression of ascorbate oxidase in the apoplast of transgenic tobacco results in altered ascorbate and glutathione redox states and increased sensitivity to ozone. Planta 216:918-928

Sano S, Tao S, Endo Y, Inaba T, Hossain MA, Miyake C, Matsuo M, Aoki H, Asada K, Saito K (2005) Purification and cDNA cloning of chloroplastic monodehydroascorbate reductase from spinach. Biosci Biotechnol Biochem 69:762-772

Sarowar S, Kim EN, Kim YJ, Ok SH, Kim KD, Hwang BK, Shin JS (2005) Overexpression of a pepper ascorbate peroxidase-like 1 gene in tobacco plants enhances tolerance to oxidative stress and pathogens. Plant Sci 169:55-63

Sato Y, Masuta Y, Saito K, Murayama S, Ozawa K (2011) Enhanced chilling tolerance at the booting stage in rice by transgenic overexpression of the ascorbate peroxidase gene. OsAPXa Plant Cell Rep 30:399-406

Shimaoka T, Miyake C, Yokota A (2003) Mechanism of the reaction catalyzed by dehydroascorbate reductase from spinach chloroplasts. Eur J Biochem 270:921-928

Siendones E, Gonzalez-Reyes JA, Santos-Ocana C, Navas P, Cordoba F (1999) Biosynthesis of ascorbic acid in kidney bean. L-galactono-gamma-lactone dehydrogenase is an intrinsic protein located at the mitochondrial inner membrane. Plant Physiol 120:907-912

Simpson GL, Ortwerth BJ (2000) The non-oxidative degradation of ascorbic acid at physiological conditions. Biochim Biophys Acta 1501:12-24

Smirnoff N (1996) The function and metabolism of Ascorbic acid in plants. Ann Bot 78:661-669

Smirnoff N (2000) Ascorbate biosynthesis and function in photoprotection. Philos Trans R Soc Lond B Biol Sci 355:1455-1464

Smirnoff N (2001) L-Ascorbic acid biosynthesis. Vitam Horm 61:241-266

Smirnoff N, Running JA, Gatzek S (2004) Ascorbate Biosynthesis: A Diversity of Pathways. In: Asard H, May JM, Smirnoff N (eds) Vitamin C. Bios Scientific Publishers, Oxford, UK, Functions and Biochemistry in Animals and Plants, pp 7-29

Stevens R, Page D, Gouble B, Garchery C, Zamir D, Causse M (2008) Tomato fruit ascorbic acid content is linked with monodehydroascorbate reductase activity and tolerance to chilling stress. Plant Cell Environ 31:1086-1096

Strasser BJ (1997) Donor side capacity of photosystem II probed by chlorophyll a fluorescence transients. Photosynth Res 52:147-155

Sun WH, Duan M, Shu DF, Yang S, Meng QW (2010a) Over-expression of StAPX in tobacco improves seed germination and increases early seedling tolerance to salinity and osmotic stresses. Plant Cell Rep 29:917-926

Sun WH, Duan M, Li F, Shu DF, Yang S, Meng QW (2010b) Overexpression of tomato tAPX gene in tobacco improves tolerance to high or low temperature stress. Biol Plant 54:614-620

Suzuki N, Mittler R (2006) Reactive oxygen species and temperature stresses: a delicate balance between signaling and destruction. Physiol Plant 126:45-51

Szarka A, Horemans N, Banhegyi G, Asard H (2004) Facilitated glucose and dehydroascorbate transport in plant mitochondria. Arch Biochem Biophys 428:73-80

Szarka A, Horemans N, Kovacs Z, Grof P, Mayer M, Banhegyi G (2007) Dehydroascorbate reduction in plant mitochondria is coupled to the respiratory electron transfer chain. Physiol Plant 129:225-232

Tabata K, Oba K, Suzuki K, Esaka M (2001) Generation and properties of ascorbic acid-deficient transgenic tobacco cells expressing antisense RNA for 1galactono 1,4-lactone dehydrogenase. Plant J 27:139-148

Talla S, Riazunnisa K, Padmavathi L, Sunil B, Rajsheel P, Raghavendra AS (2011) Ascorbic acid is a key participant during the interactions between chloroplasts and mitochondria to optimize photosynthesis and protect against photoinhibition. J Biosci 36:163-173 
Tang L, Kwon SY, Kim SH, Kim JS, Choi JS, Cho KY, Sung CK, Kwak SS, Lee HS (2006) Enhanced tolerance of transgenic potato plants expressing both superoxide dismutase and ascorbate peroxidase in chloroplasts against oxidative stress and high temperature. Plant Cell Rep 25:1380-1386

Tedone L, Hancock RD, Alberino S, Haupt S, Viola R (2004) Long-distance transport of I-ascorbic acid in potato. BMC Plant Biol 17:1-16

Teixeira FK, Menezes-Benavente L, Margis R, Margis-Pinheiro MJ (2004) Analysis of the molecular evolutionary history of the ascorbate peroxidase gene family: inferences from the rice genome. J Mol Evol 59:761-770

Teixeira FK, Menezes-Benavente L, Galvao VC, Margis R, Margis- Pinheiro M (2006) Rice ascorbate peroxidase gene family encodes functionally diverse isoforms localized in diVerent subcellular compartments. Planta 224:300-314

Tokunaga T, Miyahara K, Tabata K, Esaka M (2005) Generation and properties of ascorbic acid-overproducing transgenic tobacco cells expressing sense RNA for L-galactono- 1,4-lactone dehydrogenase. Planta 220:854-863

Torabinejad J, Donahue JL, Gunesekera BN, Allen-Daniels MJ, Gillaspy GE (2009) VTC4 is a bifunctional enzyme that affects myoinositol and ascorbate biosynthesis in plants. Plant Physiol 150:951-961

Torsethaugen C, Pitcher LH, Zilinskas BA, Pell EJ (1997) Overproduction of Ascorbate peroxidase in the tobacco chloroplast does not provide protection against ozone. Plant Physiol 114:529-537

Torsethaugen G, Pell EJ, Assmann SM (1999) Ozone inhibits guard cell K1 channels implicated in stomatal opening. Proc Natl Acad Sci U S A 96:13577-13582

Tóth SZ, Puthur JT, Nagy V, Garab G (2009) Experimental evidence for ascorbatedependent electron transport in leaves with inactive oxygen-evolving complexes. Plant Physiol 149:1568-1578

Tóth SZ, Nagy V, Puthur JT, Kovács L, Garab G (2011) The physiological role of ascorbate as photosystem II electron donor: protection against photoinactivation in heat-stressed leaves. Plant Physiol 156:382-392

Trost P, Berczi A, Sparla F, Sponza G, Marzadori B, Asard H, Pupillo P (2000) Purification of cytochrome b-561 from bean hypocotyls plasma membrane. Evidence for the presence of two heme centers. Biochim Biophys Acta 1468:1-5

Tsai YC, Hong CY, Liu LF, Kao CH (2004) Relative importance of $\mathrm{Na}^{+}$and $\mathrm{Cl}^{-}$in $\mathrm{NaCl}-$ induced antioxidant systems in roots of rice seedlings. Physiol Plant 122:86-94

Tsai YC, Hong CY, Liu LF, Kao CH (2005) Expression of ascorbate peroxidase and glutathione reductase in roots of rice seedlings in response to $\mathrm{NaCl}$ and $\mathrm{H}_{2} \mathrm{O}_{2}$. J Plant Physiol 162:291-299

Tsukaguchi H, Tokui T, Mackenzie B, Berger UV, Chen XZ, Wang YX, Brubaker RF, Hediger MA (1999) A family of mammalian $\mathrm{Na}^{+}$-dependent L-ascorbic acid transporters. Nature 399:70-75

Turcsányi E, Lyons T, Plöchl M, Barnes J (2000) Does ascorbate in the mesophyll cell walls form the first line of defence against ozone? Testing the concept using broad bean (Vicia faba L.). J Exp Bot 51:901-910

Upadhyaya CP, Venkatesh J, Gururani MA, Asnin L, Sharma K, Ajappala H, Park SW (2011) Transgenic potato overproducing $L$-ascorbic acid resisted an increase in methylglyoxal under salinity stress via maintaining higher reduced glutathione level and glyoxalase enzyme activity. Biotechnol Lett 33:2297-2307

Ushimaru T, Nakagawa T, Fujioka Y, Daicho K, Naito M, Yamauchi Y, Nonaka H, Amako K, Yamawaki K, Murata N (2006) Transgenic Arabidopsis plants expressing the rice dehydroascorbate reductase gene are resistant to salt stress. J Plant Physiol 163:1179-1184

Vacca RA, de Pinto MC, Valenti D, Passarella S, Marra E, De Gara L (2004) Production of reactive oxygen species, alteration of cytosolic ascorbate peroxidase, and impairment of mitochondrial metabolism are early events in heat shock-induced programmed cell death in tobacco bright-yellow 2 cells. Plant Physiol 134:1100-1112

Venkatesh J, Upadhyaya CP, Yu JW, Hemavathi A, Kim DH, Strasser RJ, Park SW (2012) Chlorophyll a fluorescence transient analysis of transgenic potato overexpressing D-galacturonic acid reductase gene for salinity stress tolerance. Hort Environ Biotechnol 53:320-328

Wang W, Vinocur B, Altman A (2003) Plant responses to drought, salinity and extreme temperatures: towards genetic engineering for stress tolerance. Planta 218:1-14

Wang Y, Wisniewski M, Meilan R, Webb R, Fuchigami L (2005) Overexpression of cytosolic ascorbate peroxidase in tomato (Lycopersicon esculentum) confers tolerance to chilling and salt stress. J Amer Soc Hort Sci 130:167-173

Wang Y, Wisniewski M, Meilan R, Cui M, Fuchigami L (2006) Transgenic tomato (Lycopersicon esculentum) overexpressing CAPX exhibits enhanced tolerance to UV-B and heat stress. J Appl Hort 8:87-90

Wang Z, Xiao Y, Chen W, Tang K, Zhang $L$ (2010) Increased vitamin C content accompanied by an enhanced recycling pathway confers oxidative stress tolerance in Arabidopsis. J Integr Plant Biol 52:400-409
Wang HS, Yu C, Zhu ZJ, Yu XC (2011) Overexpression in tobacco of a tomato GMPase gene improves tolerance to both low and high temperature stress by enhancing antioxidation capacity. Plant Cell Rep 30:1029-1040

Watanabe K, Suzuki K, Kitamura S (2006) Characterization of a GDP-D-mannose 3',5'-epimerase from rice. Phytochemistry 67:338-346

Wevar Oller AL, Agostini E, Milrad SR, Medina MI (2009) In situ and de novo biosynthesis of vitamin $\mathrm{C}$ in wild type and transgenic tomato hairy roots: A precursor feeding study. Plant Sci 177:28-34

Wheeler GL, Jones MA, Smirnoff N (1998) The biosynthesis pathway of vitamin C in higher plants. Nature 393:365-369

Wolucka BA, Van Montagu M (2003) GDP-mannose 3',5'- epimerase forms GDP-Lgulose, a putative intermediate for the de novo biosynthesis of vitamin C in plants. J Biol Chem 278:47483-47490

Wolucka BA, Goossens A, Inzé D (2005) Methyl jasmonate stimulates the de novo biosynthesis of vitamin C in plant cell suspensions. J Exp Bot 56:2527-2538

Xu WF, Shi WM, Ueda A, Takabe T (2008) Mechanisms of salt tolerance in transgenic Arabidopsis thaliana carrying a peroxisomal ascorbate peroxidase gene from barley. Pedosphere 18:486-495

Yabuta Y, Motoki T, Yoshimura K, Takeda T, Ishikawa T, Shigeoka S (2002) Thylakoid membrane-bound ascorbate peroxidase is a limiting factor of antioxidative systems under photo-oxidative stress. Plant J 32:915-925

Yabuta Y, Mieda T, Rapolu M, Nakamura A, Motoki T, Takanori M, Yoshimura K, Ishikawa T, Shigeoka S (2007) Light regulation of ascorbate biosynthesis is dependent on the photosynthetic electron transport chain but independent of sugars in Arabidopsis. J Exp Bot 58:2661-2671

Yamamoto A, Bhuiyan MNH, Waditee R, Tanaka Y, Oba MEK, Jagendorf AT, Takabe T (2005) Suppressed expression of the apoplastic ascorbate oxidase gene increases salt tolerance in tobacco and Arabidopsis plants. J Exp Bot 56:1785-1796

Yamashita A, Nijo N, Pospísil P, Morita N, Takenaka D, Aminaka R, Yamamoto Y, Yamamoto Y (2008) Quality control of photosystem II: reactive oxygen species are responsible for the damage to photosystem II under moderate heat stress. J Biol Chem 283:28380-28391

Yin L, Wang S, Eltayeb AE, Uddin MI, Yamamoto Y, Tsuji W, Takeuchi Y, Tanaka K (2010) Overexpression of dehydroascorbate reductase, but not monodehydroascorbate reductase, confers tolerance to aluminum stress in transgenic tobacco. Planta 231:609-621

Yoon HS, Lee H, Lee IA, Kim KY, Jo J (2004) Molecular cloning of the monodehydroascorbate reductase gene from Brassica campestris and analysis of its mRNA level in response to oxidative stress. Biochim Biopys Acta 1658:181-186

Yoshida S, Tamaoki M, Shikano T, Nakajima N, Ogawa D, loki M, Aono M, Kubo A, Kamada H, Inoue Y, Saji H (2006) Cytosolic dehydroascorbate reductase is important for ozone tolerance in Arabidopsis thaliana. Plant Cell Physiol 47:304-308

Yoshimura K, Miyao K, Gaber A, Takeda T, Kanaboshi H, Miyasaka H, Shigeoka S (2004) Enhancement of stress tolerance in transgenic tobacco plants overexpressing Chlamydomonas glutathione peroxidase in chloroplasts or cytosol. Plant J 37:21-33

Zhang X, Zhang L, Dong F, Gao J, Galbraith DW, Song CP (2001) Hydrogen peroxide is involved in abscisic acid-induced stomatal closure in Vicia faba. Plant Physiol 126:1438-1448

Zhang L, Wang Z, Xia Y, Kai G, Chen W, Tang K (2007) Metabolic engineering of plant $L$-ascorbic acid biosynthesis: recent trends and applications. Crit Rev Biotechnol 27:173-182

Zhang W, Lorence A, Gruszewski HA, Chevone BI, Nessler CL (2009) AMR1, an Arabidopsis gene that coordinately and negatively regulates the mannose//galactose ascorbic acid biosynthetic pathway. Plant Physiol 150:942-950

Zhang C, Liu J, Zhang Y, Cai X, Gong P, Zhang J, Wang T, Li H, Ye Z (2011) Overexpression of SIGMEs leads to ascorbate accumulation with enhanced oxidative stress, cold, and salt tolerance in tomato. Plant Cell Rep 30:389-398

Zhang Z, Zhang Q, Wu J, Zheng X, Zheng S, Sun X, Qiu Q, Lu T (2013) Gene knockout study reveals that cytosolic ascorbate peroxidase 2 (OSAPX2) plays a critical role in growth and reproduction in rice under drought, salt and cold stresses. PLoS One 8(2):e57472, doi: 10.1371/journal.pone.0057472

Zheng Y, Lyons T, Ollerenshaw JH, Barnes JD (2000) Ascorbate in the leaf apoplast is a factor mediating ozone resistance in Plantago major. Plant Physiol Biochem 38:403-411

doi:10.1186/1999-3110-55-38

Cite this article as: Venkatesh and Park: Role of L-ascorbate in alleviating abiotic stresses in crop plants. Botanical Studies 2014 55:38. 